\title{
Convergence of genetic and environmental factors on parvalbumin-positive interneurons in schizophrenia
}

\author{
Zhihong Jiang $^{1}{ }^{*}$, Rita M. Cowell ${ }^{2}$ and Kazu Nakazawa ${ }^{*}$ \\ ${ }^{1}$ Unit on Genetics of Cognition and Behavior, National Institute of Mental Health, NIH, Bethesda, MD, USA \\ ${ }^{2}$ Department of Psychiatry and Behavioral Neurobiology, University of Alabama at Birmingham, Birmingham, AL, USA
}

\section{Edited by:}

Tim Karl, Neuroscience Research

Australia, Australia

Reviewed by:

Gil D. Hoftman, University of

Pittsburgh, USA

Dipesh Joshi, Neuroscience Research

Australia, Australia

*Correspondence:

Zhihong Jiang or Kazu Nakazawa, National Institute of Mental Health, 35

Convent Drive, Building 35, Room

1C915, Bethesda, MD 20892-3710,

USA

e-mail: zhihongjiang@mail.nih.gov;

nakazawk@mail.nih.gov
Schizophrenia etiology is thought to involve an interaction between genetic and environmental factors during postnatal brain development. However, there is a fundamental gap in our understanding of the molecular mechanisms by which environmental factors interact with genetic susceptibility to trigger symptom onset and disease progression. In this review, we summarize the most recent findings implicating oxidative stress as one mechanism by which environmental insults, especially early life social stress, impact the development of schizophrenia. Based on a review of the literature and the results of our own animal model, we suggest that environmental stressors such as social isolation render parvalbumin-positive interneurons (PVIs) vulnerable to oxidative stress. We previously reported that social isolation stress exacerbates many of the schizophrenia-like phenotypes seen in a conditional genetic mouse model in which NMDA receptors (NMDARs) are selectively ablated in half of cortical and hippocampal interneurons during early postnatal development (Belforte et al., 2010). We have since revealed that this social isolation-induced effect is caused by impairments in the antioxidant defense capacity in the PVIs in which NMDARs are ablated. We propose that this effect is mediated by the down-regulation of PGC- $1 \alpha$, a master regulator of mitochondrial energy metabolism and anti-oxidant defense, following the deletion of NMDARs (Jiang et al., 2013). Other potential molecular mechanisms underlying redox dysfunction upon gene and environmental interaction will be discussed, with a focus on the unique properties of PVIs.

Keywords: animal model, fast-spiking neurons, GABA neuron, NMDA receptors, oxidative stress, PGC-1 $\alpha$, social isolation

\section{INTRODUCTION}

Schizophrenia is a chronic and complex neuropsychiatric disorder that affects approximately $1 \%$ of the population worldwide (Insel, 2010). The characteristic features of schizophrenia have been categorized into three major symptom domains (DSM-IV, American Psychiatric Association, 1994). Positive symptoms are psychotic behaviors not seen in healthy people, such as hallucillations, delusions, disorganized thinking, and movement disorders which, in part, can be relieved through the use of current antipsychotic medications. Negative symptoms are associated with disruption of normal emotions and behaviors, such as motivational impairment (avolition or amotivation), affective dysregulation (depression, mania), and social withdrawal. Cognitive symptoms include poor executive functioning, trouble focusing or paying attention, and problems with working memory. The onset of symptoms usually occurs during late adolescence and early adulthood.

Based on classical family, twin and adoption studies, genetic theories of schizophrenia etiology have been prominent since 1960s (Gottesman and Shields, 1976; Cardno and Gottesman, 2000; Carter et al., 2002; Sullivan et al., 2003; Tienari et al., 2004; Lichtenstein et al., 2009). Early linkage studies produced the first list of gene candidates, and a large body of gene association work identified some of these candidate genes as true susceptibility factors (Owen et al., 2005; Ross et al., 2006; Straub and Weinberger, 2006). Recently, analysis of data generated using genomewide mass-marker technology (such as genome-wide association studies (GWAS) and next generation sequencing) has raised the possibility that thousands of common polymorphisms (Purcell et al., 2009) and multiple rare copy-number variations (CNVs) in several different genomic areas contribute to schizophrenia risk (Stefansson et al., 2008; Stone et al., 2008; Walsh et al., 2008; Xu et al., 2008; McCarthy et al., 2009; Ingason et al., 2011). Although GWAS from the psychiatric genomics consortium (PGC), a collaboration across more than 300 scientists in 80 institutions and 20 countries, have been carried out to investigate a large number of polymorphisms from thousands of patients $(61,220$ subjects, Smoller et al., 2013), no single gene or allele has independently been identified as a key risk factor in a large number of people.

One plausible explanation for the weak association of schizophrenia with an individual gene is that genetic risk is critically dependent on environmental context. A considerable body of evidence suggests that an interaction between genetic 
vulnerability and environmental factors (GxE) leads to the manifestation of schizophrenia. Even monozygotic twins who share identical genes have a concordance rate of 41-65\% (Cardno and Gottesman, 2000). Epidemiologic studies suggest that a diversity of factors, including prenatal infection/immune activation, paternal age, malnutrition, hypoxia-related obstetric complications, and childhood/adolescence social stress and cannabis abuse, are associated with an increased risk for the development of this disorder (see reviews, Barkus and Murray, 2010; van Os et al., 2010; Brown, 2011; Meyer, 2013).

Various theories have been proposed to explain how genes and the environment interact to give rise to complex neuropsychiatric disorders. The "Diathesis-stress" model of schizophrenia, introduced by Rosenthal D. and Bleuler M. in 1963 (Ingram and Luxton, 2005) and recently revisited by Fowles (1992), posits that development of schizophrenia requires both biological vulnerability (diathesis) and stressful life. Weinberger (1987) went on to propose a similar model in the context of brain development and maturation, suggesting that an environmental stressor during early life brain maturation is necessary to trigger the onset of full-blown psychotic behavior. In the framework of the neurodevelopmental theory, a "two-hit" model was proposed and two critical time windows associated with brain early development and maturation during adolescence were identified as sensitive periods for exposure to environmental insults that could account for the emergence of symptoms of schizophrenia (Bayer et al., 1999; Keshavan, 1999).

However, there is a fundamental gap in our understanding of the molecular mechanisms by which environmental factors interact with genetic susceptibility during brain development to trigger psychosis. A large number of neurodevelopmental animal models have been developed to investigate the biological basis for GxE interactions and to evaluate novel pharmacological therapies for their treatment (review, Meyer and Feldon, 2010). For example, inflammatory responses after infection and cytokinemediated effects on brain development have been studied using polyinosinic:polycytidylic acid (poly I:C) and lipopolysaccharide (LPS) in rodents; protein deprivation and vitamin D deficiency to mimic malnutrition; perinatal/postnatal hypoxia models for obstetric complications; maternal isolation, post-weaning social isolation/chronic restraint stress have been used to study psychosocial stress effects on brain development. Genetic manipulation of schizophrenia susceptibility genes in rodents, such as DISC1, NRG1/ErbB4, and COMT has been largely explored as well.

Interestingly, one of the common findings in both animal models and postmortem tissue from patients with schizophrenia is a reduction of the calcium buffer parvalbumin (PV) mRNA or protein level in cortical fast-spiking (FS) interneurons. PVpositive interneurons (PVIs), which account for $\sim 40 \%$ of the total cortical Gamma-amminobutyric acid (GABA) ergic interneurons in rodents (Rudy et al., 2011) and 25\% in primates (Condé et al., 1994) and include basket and chandelier cells, represent a unique class of interneurons. A significant mRNA reduction of PV (Hashimoto et al., 2003, 2008; Mellios et al., 2009; Fung et al., 2010; Volk et al., 2012), GAD67 (Hashimoto et al., 2003; Curley et al., 2011) or GAT1 (Volk et al., 2012) has been found in PVIs in the dorsolateral prefrontal cortex of individuals with schizophrenia. Altered GABA neurotransmission at the synapse between PV-positive chandelier neurons and the pyramidal cell axon initial segment (AIS), such as decreased density of chandelier neuron axon cartridges immunoreactive for GAT-1 (Woo et al., 1998; Pierri et al., 1999), increased $\mathrm{GABA}_{A}$ receptor $\alpha 2$ subunit at AIS of pyramidal neurons (Volk et al., 2002) and increased $\mathrm{GABA}_{A}$ receptor binding (Benes et al., 1992, 1996), was also found in schizophrenic patients. Furthermore, factors required for development of PVI including the transcription factor Lhx6 and brain derived neurotrophic factor (BDNF) and its receptors are reduced in a subset of individuals with schizophrenia (Cobos et al., 2006; Liodis et al., 2007; Zhao et al., 2008, see reviews, Huang et al., 1999; Weickert et al., 2003; Hashimoto et al., 2005; Weickert et al., 2005; Woo and Lu, 2006; Volk et al., 2012).

Dysfunction of PVIs has been indicated in many neurodevelopmental animal models as well. Studies in reverse-translational models using schizophrenia-risk genes, such as ErbB4 (Fisahn et al., 2009; Neddens and Buonanno, 2010), DISC1 (Hikida et al., 2007; Shen et al., 2008; Ayhan et al., 2011), DTNP1 (Ji et al., 2009; Carlson et al., 2011), BDNF (Sakata et al., 2009) and glutamate cysteine ligase modifier (GCLM; Steullet et al., 2010; Cabungcal et al., 2013a), consistently observed a decreased number or impaired function of PVIs in the hippocampus or cortex. Also, intensity of PV immunoreactivity and/or loss of PV-positive cells has been reported in the hippocampus and cortex of mice with developmental inflammation [prenatal poly I:C injection (Meyer et al., 2008; Ducharme et al., 2012; Piontkewitz et al., 2012); neonatal LPS injection (Jenkins et al., 2009)], exposure to hypoxia (Gerstein et al., 2005; Fagel et al., 2009), chronic social isolation stress (Harte et al., 2007; Schiavone et al., 2009, 2012; Filipovic et al., 2013), ventral hippocampal lesions (Tseng et al., 2008; François et al., 2009) or prenatal (E17) methylazoxymethanol acetate (MAM) injections (Lodge et al., 2009; Gastambide et al., 2012). Pharmacological manipulation by NMDA receptor (NMDAR) antagonists, such as repetitive injection of ketamine (Behrens et al., 2007), prenatal exposure to MK-801 (Abekawa et al., 2007) or perinatal phencyclidine (PCP) injection (Wang et al., 2008), all resulted in a decrease in the number of cortical PVIs. These data suggest that PV immunoreactivity and PVI cells themselves are particularly sensitive to neurodevelopmental insults.

PVI cell loss and dysfunction have serious consequences for cortical and hippocampal function. PVIs produce sustained, high-frequency trains of brief action potentials with large and fast after-hyperpolarization and little spike frequency adaptation. They have the lowest input resistance and the fastest membrane time constant among all interneurons, features that ensure fast synaptic responses (Connors and Gutnick, 1990; Markram et al., 2004; Ascoli et al., 2008; Goldberg et al., 2008). FS PVIs are interconnected via chemical and electrical synapses (Galarreta and Hestrin, 1999; Gibson et al., 1999) and have a highly divergent synaptic output to principle neurons (Gulyás et al., 1999). Inhibitory synapses between PVIs synchronize action potential activity within basket cell network, whereas inhibitory synapses between basket cells and principle neurons distribute this synchronized activity to the principle neuron 
population. Accordingly, multiple lines of evidence indicate that FS PVIs are essential for the generation of gamma oscillations (Csicsvari et al., 2003; Hájos et al., 2004; Mann et al., 2005; Cardin et al., 2009; Sohal et al., 2009), which provides a temporal structure for information processing and contributes to cognitive functions including attention (Fries et al., 2001, 2008; Siegel et al., 2008), perception (Rodriguez et al., 1999) and working memory (Howard et al., 2003). Cognitive impairments such as deficits in working memory, attention, and executive function are particularly evident in patients with schizophrenia (Elvevåg and Goldberg, 2000), and abnormalities in gamma oscillations may contribute to these deficits. Schizophrenic patients exhibit decreases in the power or synchrony of gamma oscillations during responses to sensory stimulation or cognitive tasks (Gallinat et al., 2004; Spencer et al., 2004; Symond et al., 2005; Wynn et al., 2005; Cho et al., 2006; Ford et al., 2007, 2008; Haenschel et al., 2009; Uhlhaas and Singer, 2010). Thus, abnormalities of FS PVIs may underlie the cognitive disturbances associated with schizophrenia.

Considering the substantial evidence for interneuron dysfunction and NMDAR hypofunction in schizophrenia, we investigated the impact of NMDAR deletion specifically from interneurons using a Cre/loxP system in which early postnatal ablation is restricted to $40-50 \%$ of the cortical and hippocampal interneurons, with the majority of cre-targeted cells being PV-positive [NMDAR (GluN1) knockout mouse strain (Ppp1r2-cre/fGluN1 KO mice; Belforte et al., 2010)]. In this mouse, NMDARs were functionally eliminated in the early postnatal period (Cre recombination was detectable in the cortex and hippocampus firstly at postnatal day seven and almost completed by postnatal three weeks). Reduced GAD67 and PV protein levels and reduced GABA release were observed from GluN1-depleted interneurons in mutant animals, and mutant mice exhibited cortical disinhibition evidenced by increased firing of cortical excitatory neurons and reduced neuronal synchrony. At the behavioral level, this mutant mouse reproduced positive, negative, cognitive and anxiety-like behavioral phenotypes that resemble the symptoms of human schizophrenia. Most mutant behavioral phenotypes were first observed $>12$ weeks of age, suggesting a latency period between GluN1 knockout and the emergence of these phenotypes (Belforte et al., 2010; Nakazawa et al., 2012). Interestingly, social isolation initiated during adolescence exacerbated the expression of these phenotypes in the mutant (Jiang et al., 2013).

Importantly, schizophrenia-like pathophysiological and behavioral phenotypes were not observed when genetic GluN1 ablation in the same subpopulations of GABAergic (gammaaminobutyric acid) neurons occurred after adolescence (Belforte et al., 2010), suggesting that GluN1 deletion is most detrimental during the postnatal maturation of PVIs. Furthermore, a prominent increase of oxidative stress was observed in $\mathrm{KO}$ mice, particularly in cortical PVIs, with post-weaning social isolation sharply exacerbating redox dysfunction. Chronic treatment with apocynin (APO), an antioxidant and reactive oxygen species (ROS) scavenger, abolished oxidative stress signs and partially alleviated schizophrenia-like behavioral phenotypes in $\mathrm{KO}$ mice (Jiang et al., 2013).
In the context of this new data and the substantial evidence for PVI dysfunction in schizophrenia, we propose that social isolation in development exacerbates schizophrenia-like phenotypes via cortical oxidative stress in PVIs (Jiang et al., 2013). These data are in line with the "diathesis-stress" and neurodevelopmental theories for the etiology of schizophrenia and suggest that oxidative stress is one of central factors linking genetic and environmental risks to GABAergic dysfunction (Figure 1). Below, we discuss in detail the evidence for the involvement of oxidative stress in the pathophysiology of schizophrenia, the specific properties of PVIs that render them vulnerable to oxidative stress, and a potential molecular pathways which could account for environmentallyinduced oxidative stress in PVIs.

\section{OXIDATIVE STRESS AS A CONVERGENCE POINT FOR GENETIC AND ENVIRONMENTAL SUSCEPTIBILITY TO SCHIZOPHRENIA}

Growing body of evidence suggests that oxidative stress plays a significant role in the pathogenesis of schizophrenia (see reviews, Behrens and Sejnowski, 2009; Do et al., 2009; Yao and Keshavan, 2011). Oxidative stress occurs when ROS or reactive nitrogen species (RNS) are over-produced or antioxidant defense mechanisms fail to counterbalance endogenouse ROS/RNS generated from normal oxidative metabolism or from pro-oxidant environmental exposure. Excessive ROS or RNS can lead to DNA damage and membrane damage due to lipid peroxidation and protein dysfunction. Mammalian antioxidant defense system include ROS detoxifying enzymes such as superoxide dismutases (SOD), catalase (CAT) and glutathione peroxidase ( $\mathrm{Gpx}$ ), and nonenzymatic antioxidant components such as albumin, uric acid, bilirubin, glutathione (GSH), ascorbic acid (vitamin C) and a-tocopherol (vitamin E). Reduced levels of ROS detoxifying enzymes and antioxidants have been reported in schizophrenia (Suboticanec et al., 1990; Reddy et al., 1991; McCreadie et al., 1995; Mukerjee et al., 1996; Yao et al., 1998, 2000; Do et al., 2000; Ranjekar et al., 2003; Reddy et al., 2003; Yao et al., 2006; Dadheech et al., 2008; Raffa et al., 2009; Gawryluk et al., 2011; Coughlin et al., 2013 ), in addition to increased levels of lipid peroxides in blood (Zhang et al., 2006; Al-Chalabi et al., 2009; Padurariu et al., 2010), platelets (Dietrich-Muszalska et al., 2005), plasma (Mahadik et al., 1998) and urine (Dietrich-Muszalska and Olas, 2009a). Increased protein modification has been also demonstrated in plasma (Dietrich-Muszalska et al., 2009), platelets (Dietrich-Muszalska and Olas, 2009b) and postmortem brains (Wang et al., 2009).

\section{GENETIC ORIGIN OF OXIDATIVE STRESS}

Interestingly, a number of genes involved in antioxidant defense have been linked to susceptibility for schizophrenia. These include MnSOD (Akyol et al., 2005), glutathione S-transferases (Saadat et al., 2007; Nafissi et al., 2011), and a subunit of the key GSHsynthesizing enzyme GCLM (Tosic et al., 2006; Gysin et al., 2007, 2011). A mitochondrial DNA sequence variation affecting a subunit of NADPH-ubiquinone reductase (complex I), a component of the electron transport chain responsible for generating superoxide, has also been associated with schizophrenic patients and with increased superoxide levels in postmortem brain samples (Marchbanks et al., 2003). Furthermore, abnormal proteins 


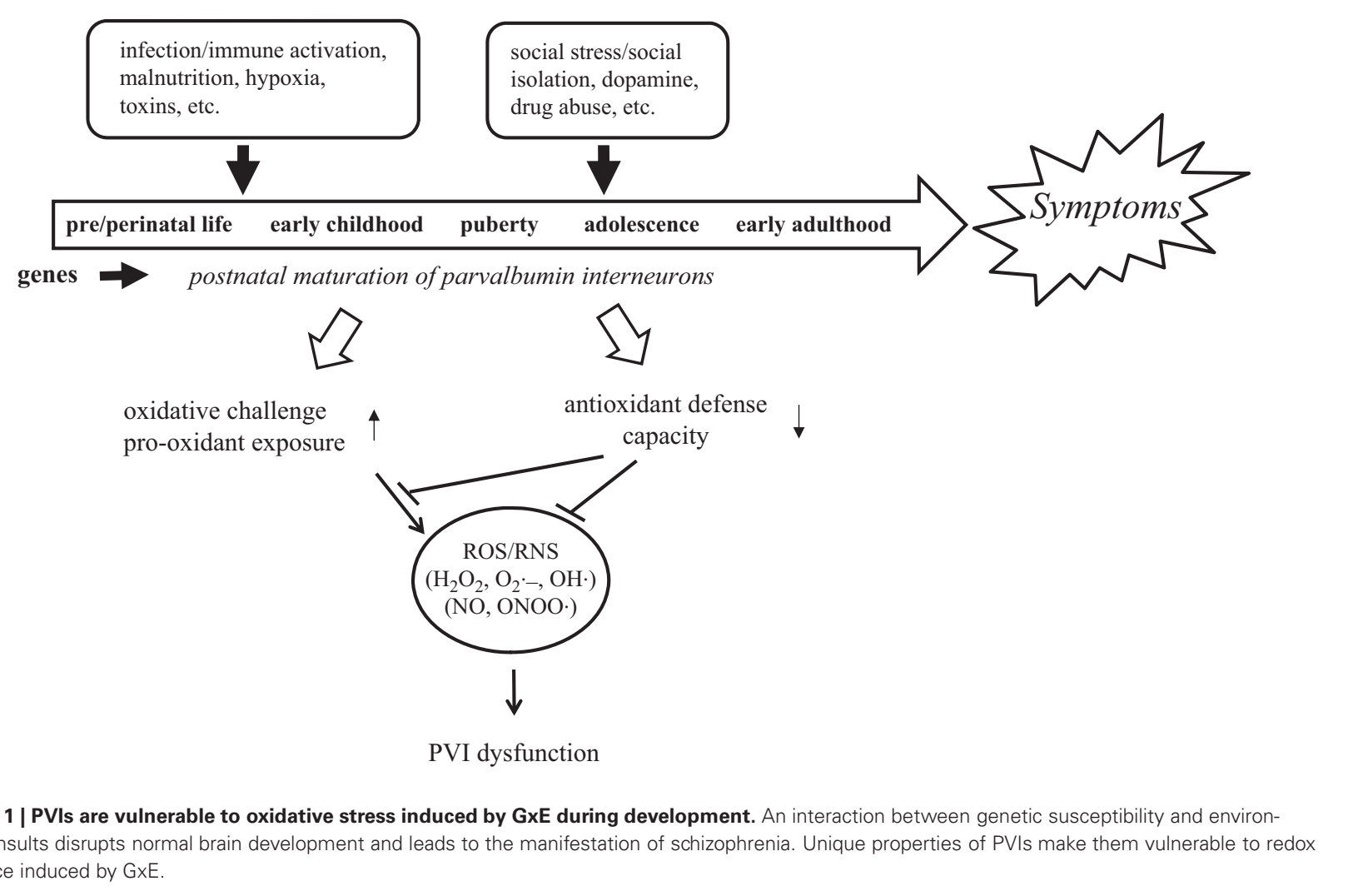

encoded by schizophrenia susceptibility genes (PRODH, DISC1, DAOA, NRG1, G72) cause oxidative stress and/or hypersensitivity to oxidative stress (Goldshmit et al., 2001; Krishnan et al., 2008; Drews et al., 2012) or mitochondrial dysfunction (Park et al., 2010).

\section{OXIDATIVE STRESS INDUCED BY ENVIRONMENTAL INSULTS}

In addition to our own evidence for social isolation-induced oxidative stress, other studies have demonstrated links between environmental stressors and oxidative stress. ROS elevation was found after restraint stress (Madrigal et al., 2001; Chakraborti et al., 2007; Sahin and Gumuslu, 2007), and social isolation rearing in rats induces behavioral changes akin to schizophrenia, mediated by an oxidative stress following NADPH oxidase (Nox-2) elevation in pyramidal neurons (Schiavone et al., 2009,2012 ) or associated with decreased superoxide dismutase activity and oxidized/reduced glutathione ratio in the corticostriatal area (Möller et al., 2011). As in our model, APO treatment alleviated the signs of oxidative stress and behavioral deficits following social isolation (Schiavone et al., 2009, 2012). Furthermore, oxidative stress has been speculated to be an important downstream mechanism of inflammation-mediated immune responses. Maternal immune activation by LPS in rodents triggers oxidative stress (Lanté et al., 2007; Kaneko et al., 2012; Oskvig et al., 2012), and maternal $\mathrm{N}$-acetyl cysteine (NAC, a glutathione precursor) treatment prevents LPS-induced adverse developmental outcomes including elevation of cytokines in maternal and fetal compartments (Xu et al., 2005; Beloosesky et al., 2006), fetal death, preterm labor (Buhimschi et al., 2003), hypomyelination (Paintlia et al., 2004), and impairments in spatial memory and hippocampal long-term potentiation in the offspring (Lanté et al., 2007). Protein malnutrition (Feoli et al., 2006a,b) and hypoxia (Dafre et al., 2003; Sheldon et al., 2008; Niatsetskaya et al., 2012) can also increase oxidative stress.

\section{GXE-INDUCED OXIDATIVE STRESS}

A number of studies have investigated whether prenatal and/or postnatal environmental insults interact with specific genetic factors to cause oxidative stress and increase the risk of long-lasting neurodevelopmental brain dysfunction. Using mice which exihibit a $60-70 \%$ reduction in GSH due to ablation of the GCLM gene, Kim Q. Do and her colleagues have shown that impaired GSH synthesis is associated with morphological, neurochemical anomalies and behavioral phenotypes similar to those in schizophrenia patients (Steullet et al., 2010; Kulak et al., 2012). They also found elevated oxidative stress indicated by increased levels of 8-oxo-7, 8-dihydro-2'-deoxyguanosine (8-OH-dG), a marker of oxidized DNA, in ventral hippocampus and anterior cingulate cortex (Steullet et al., 2010; Cabungcal et al., 2013a). An exogenous dopamine stress induced by a dopamine reuptake inhibitor, GBR-12909, led to exacerbated 8-OH-dG labeling in the anterior cingulate cortex of GCLM KO mice but not wild-type mice. Treatment with NAC fully prevented the increase in 8-OHdG labeling induced by GBR-12909 in KO mice (Cabungcal et al., 2013a). 
In light of our recent study indicating an interaction between NMDAR hypofunction and oxidative stress (Jiang et al., 2013), it is important to note that the relationship of NMDAR hypofunction to oxidative stress was initially observed in the rodent models treated with NMDAR antagonists. Chronic perinatal PCP administration reduced glutathione levels and produced longterm alteration of antioxidant defense in the corticolimbic areas of the rat brain (Radonjic et al., 2010). Similarly, repetitive exposure to ketamine, another NMDAR antagonist, activated the superoxide-producing enzyme Nox-2 in mouse brains (Behrens et al., 2007; Zhang et al., 2008). Elevation of cortical ROS level was also found in our Ppp1r2-cre/fGluN1 KO mice when NMDAR was eliminated in cortical PVIs during early postnatal period. Interestingly, post-weaning social isolation sharply exacerbated ROS level in KO mice. Chronic treatment with APO abolished oxidative stress signs and partially alleviated schizophrenia-like behavioral phenotypes in $\mathrm{KO}$ mice. These indicated that oxidative stress does contribute to behavioral impairments of this mutant line and social isolation exacerbated schizophrenia-like phenotypes via cortical oxidative stress (Jiang et al., 2013).

\section{PV INTERNEURON-SPECIFIC VULNERABILITY TO OXIDATIVE STRESS}

It has been observed in several lines of animal studies that PVIs are vulnerable to oxidative stress during development. Behrens et al. $(2007,2008)$ found that repetitive adult exposure to the NMDAR antagonist ketamine increases the levels of the proinflammatory cytokine interleukin-6 (IL-6) in brain which, through activation of the superoxide-producing enzyme Nox-2, leads to the loss of the GABAergic phenotype of PVIs. Pretreatment of animals with APO, or with the SOD-mimetic C3 reduces superoxide production and prevents the loss of PV immunoreactivity (IR) induced by ketamine. Nox-2 deficiency completely prevented the loss of PVIs in the prelimbic regions (Behrens et al., 2008). The reversible effects in adult exposure (Behrens et al., 2008) were not observed for the animals with perinatal exposure of ketamine, suggesting that perturbation of the excitatory/inhibitory balance during early life produces oxidative stress that has profound effect on PVI maturation. In fact, exposure of wild type mice to ketamine on postnatal day 7, 9, and 11 is sufficient to cause a reduction in PV-IR in adulthood without death of interneurons (Powell et al., 2012), suggesting that blockade of NMDAR signaling is sufficient to alter the expression profile of FS interneurons.

The idea that PVIs are more susceptible to oxidative stress during development is also supported by the evidence that early postnatal PCP injection can selectively reduce PVI numbers (Wang et al., 2008; Nakatani-Pawlak et al., 2009) and cause redox dysregulation (Radonjic et al., 2010) in corticolimbic areas. Cabungcal et al. (2007) showed that a transient brain GSH deficit induced by BSO (Lbuthionine-(S, R)-sulfoximine) during early postnatal period is sufficient to cause cognitive impairment as well as decreased numbers of PVIs in adulthood. Using GCLM KO mice, Cabungcal et al. (2013a) demonstrated that impaired synthesis of glutathione delays maturation of PVIs in the anterior cingulate cortex as indicated by reduced PVI numbers, but not calretinin and calbidin positive interneuron numbers, and a reduction in the density of perineuronal nets (PNNs), specialized extracellular matrix components concentrated around PVIs. These effects of reduced glutathione synthesis were only evident during early development but not in later stages. More interestingly, they found that an additional oxidative challenge induced by the dopamine reuptake inhibitor GBR-12909 in preweaning or pubertal but not in young adult GCLM KO mice reduces the number of PVIs in anterior cingulate cortex. Additionally, PVIs in rats with a neonatal central hippocampal lesion exhibit oxidative stress prior to symptom onset as indicated by increased 8$\mathrm{OH}-\mathrm{dG}$ marker intensity in most PVIs in the prefrontal cortex (O'Donnell, 2012). Treatment with the GSH precursor NAC during juvenile and adolescent periods reverses the loss of PVIs and restores deficits in prepulse inhibition (O'Donnell, 2012). Collectively, these data suggest that PVIs are vulnerable to oxidative stress, particularly during their development. In our Ppp1r2cre/fGluN1 KO mice, we observed the reduction of PV-IR and oxidative stress increase on cortical PVIs, not calretinin or calbidin positive interneurons, following the post-weaning social isolation. Reduction of PV-IR upon social isolation was prevented by chronic treatment of APO, suggesting that reduced PV protein level is associated with elevated oxidative stress in PVIs (Jiang et al., 2013).

\section{POSTNATAL DEVELOPMENT AND MATURATION OF FAST-SPIKING PVIs}

Specific vulnerability of PVIs to developmental stressors that cause oxidative stress could result from their relatively late time course of maturation. The mammalian GABAergic system develops slowly during early postnatal life; in the neonatal brain, GABA is the principal excitatory transmitter that induces depolarization and that are important for the early development of the neural network (Ben-Ari et al., 2004). Conversion of GABAergic transmission from depolarizing to hyperpolarizing during the first postnatal week in rodents depends on the expression of the $\mathrm{K}+/ \mathrm{Cl}$ - cotransporter (KCC2) and the $\mathrm{Cl}$ - electrochemical potential (Ben-Ari et al., 2004, 2012). GABA signaling not only regulates interneuron axon branching and synapse formation during the maturation of inhibitory innervations (Chattopadhyaya et al., 2007) but also regulate synapse elimination and axon pruning (Wu et al., 2012).

Studies on multiple mammalian species have shown that cortical FS PVIs develop dramatically during early postnatal life. In rodents, transcriptional and electrophysiological maturation of neocortical FS interneurons from slow (low gamma band frequency) into fast (upper gamma band) signaling devices occurs over the first four weeks (Doischer et al., 2008; Okaty et al., 2009; Goldberg et al., 2011). PVIs start to express parvalbumin mRNA and protein by postnatal first week (de Lecea et al., 1995; Itami et al., 2007). The electrochemical properties of PVIs change around the same developmental age; the K+ channel subunits Kv3.1 and Kv3.2, sodium channels Scn8a and Scn 4 b, and two-pore K+ leak channels TWIK1 and TASK1 are developmentally regulated and contribute to the establishment of the FS behavior characteristics of PVIs (Du et al., 1996; Rudy and McBain, 2001; Tansey et al., 2002; Grieco and Raman, 2004; Grieco et al., 2005; Levin et al., 2006; Okaty et al., 2009; Goldberg et al., 2011). It was also found that the synaptogenesis 
of both electrical and GABAergic connections among FS PVIs and PVI-pyramidal neuron microcircuit in rodent was not established until the second postnatal week (Pangratz-Fuehrer and Hestrin, 2011; Yang et al., 2012), and maturation of perisomatic innervations by PVIs is activity and experience dependent (Chattopadhyaya et al., 2004; Jiao et al., 2006). Mature PVIs are wrapped by PNNs, and removal of PNNs increased the excitability of interneurons (Dityatev et al., 2007). Recently it was revealed that PNNs protected mature PVIs against oxidative stress and excessive ROS challenge during early life disrupted PNNs maturation around PVIs and made them more susceptible to oxidative stress (Cabungcal et al., 2013b).

A critical period for PVI maturation is adolescence. Studies in rodents, primates and human subjects indicate that expression of PV protein or mRNA and the density of PVIs processes increase during the pre-pubertal period, peaking during adolescence (Anderson et al., 1995; Erickson and Lewis, 2002; Fung et al., 2010; Caballero et al., 2013). FS PVIs in PFC undergo dramatic changes in the composition of glutamatergic receptors during adolescence: the NMDA/AMPA ratio is dramatically decreased in adolescence, but returns to juvenile levels in adults (Wang and Gao, 2009) and more FS PVIs express calcium permeable AMPA receptors during adolescence (Wang and Gao, 2010). Dopamine modulation of FS PVIs changes dramatically during adolescence (Tseng and O'Donnell, 2007; O'Donnell, 2010, review). Interestingly, in a human study, Uhlhaas et al. (2009) found that cortical networks undergo a transient destabilization from late adolescence to early adulthood, reflected by significant reductions of phase synchrony and induced gamma-band power.

\section{THE HIGH ENERGY DEMAND OF PVIs}

The majority of PVIs are FS (86\%, Pawelzik et al., 2002) and PVIs receive extremely dense excitatory innervations (Gulyás et al., 1999), suggesting that PVIs are often in a depolarized state. As a consequence of intense neuronal firing, the constant requirement for maintenance of sodium and potassium balance puts a high demand on cellular energetics. Consistent with this idea, PVIs have particularly larger numbers of mitochondria and higher cytochrome c content than other neurons (Gulyás et al., 2006). Also, it was recently reported that gamma oscillations are also especially energy demanding and require both high level of complex I and strong functional performance of mitochondria. Kann et al. (2011) found that the amount of oxygen consumption of gamma oscillations reaches that of seizure-like events, and gamma oscillations utilize mitochondrial oxidative capacity near limit. Groups of studies indicated that gamma oscillations are exquisitely sensitive to mitochondrial dysfunction (Fano et al., 2007; Huchzermeyer et al., 2008; Hájos et al., 2009; Pietersen et al., 2009; Whittaker et al., 2011) under conditions with a variety of mitochondrial respiratory chain inhibitors through an effect on FS interneurons. Interestingly, Kann et al. (2011) found that gamma oscillation power, oxygen consumption and complex I subunits are particularly higher in hippocampal subfield CA3. Kim Q. Do and her colleagues observed a selective increase of oxidative stress and a decrease of PV-IR interneu- rons in ventral CA3/DG in GCLM KO mice with a deficit of antioxidant capacity in the brain (Steullet et al., 2010). This may be related to particularly high energy demanding in these areas.

In line with a high metabolic rate of PVIs, these neurons (and transcription of PV itself) are especially vulnerable to stimuli that compromise mitochondrial function. For example, PVIs in the striatum are sensitive to 6-hydroxydopamine (Salin et al., 2009), quinolic acid (Giampà et al., 2006), rotenone (Lapointe et al., 2004), and methamphetamine (Zhu et al., 2006) and developmental injections of 3-nitropropionic acid (3-NP) cause a long-term loss of PV protein (Gibson and Clowry, 2003). Of particular interest is the vulnerability of cortical, hippocampal, and striatal PVIs to perinatal anoxia/hypoxia (Dell'Anna et al., 1996; Van de Berg et al., 2003; Gerstein et al., 2005; Wang et al., 2011) and global ischemia (Guan et al., 2000; Meade et al., 2000), considering that perinatal complications and/or hypoxia could be significant environmental factors contributing to the development of schizophrenia.

\section{PGC-1 $\alpha$ AS A MOLECULAR TARGET OF PVI-SPECIFIC GxE}

Recent evidence suggests that a critical regulator of antioxidant capacity in PVI could be the transcriptional coactivator peroxisome proliferator activated receptor gamma (PPARgamma) coactivator $1 \alpha(\mathrm{PGC}-1 \alpha)$.

\section{PGC-1 $\alpha$ DRIVES DEVELOPMENTAL TRANSCRIPTIONAL PROGRAMS FOR INCREASED ANTIOXIDANT CAPACITY, PARVALBUMIN TRANSCRIPTION, AND MITOCHONDRIAL FUNCTION}

PGC- $1 \alpha$, initially coined the "master regulator of metabolism," is highly expressed in tissues with high energy demands, such as brown adipose tissue, heart, liver, skeletal muscle and brain (Puigserver et al., 1998). It has been found to serve as a central component of the transcriptional regulatory circuity that coordinately controls the energy-generating functions of mitochondria (Figure 2). It is capable of driving transcriptional control of mitochondrial biogenesis through direct interaction with, and coactivation of, PPARs (Madrazo and Kelly, 2008), estrogen-related receptors (ERRs; Schreiber et al., 2004; Eichner and Giguère, 2011), nuclear respiratory factors (NRF-1/NRF-2; Wu et al., 1999; Scarpulla, 2011) and the transcription factor yin-yang one (YY1; Basu et al., 1997; Seelan and Grossman, 1997; Cunningham et al., 2007; Xi et al., 2007), which are important nuclear transcription factors controlling mitochondrial metabolism (Scarpulla et al., 2012). PGC- $1 \alpha$ is also an inducible responder to cellular energetic and metabolic stress, such as cold exposure (Puigserver et al., 1998; Uldry et al., 2006; Fisher et al., 2012), nutrient deprivation (Herzig et al., 2001; Yoon et al., 2001; Handschin et al., 2005; Rhee et al., 2006) and exercise (Baar et al., 2002; Handschin and Spiegelman, 2008) and is dynamically regulated in response to a variety of signaling pathways involved in cellular growth, differentiation and energy metabolism. Additionally, a large amount of evidence suggests that PGC- $1 \alpha$ links mitochondrial biogenesis and the response to oxidative stress. PGC- $1 \alpha$ has been shown to be a powerful regulator of ROS metabolism (St-Pierre et al., 2006; Cunningham et al., 2007). 


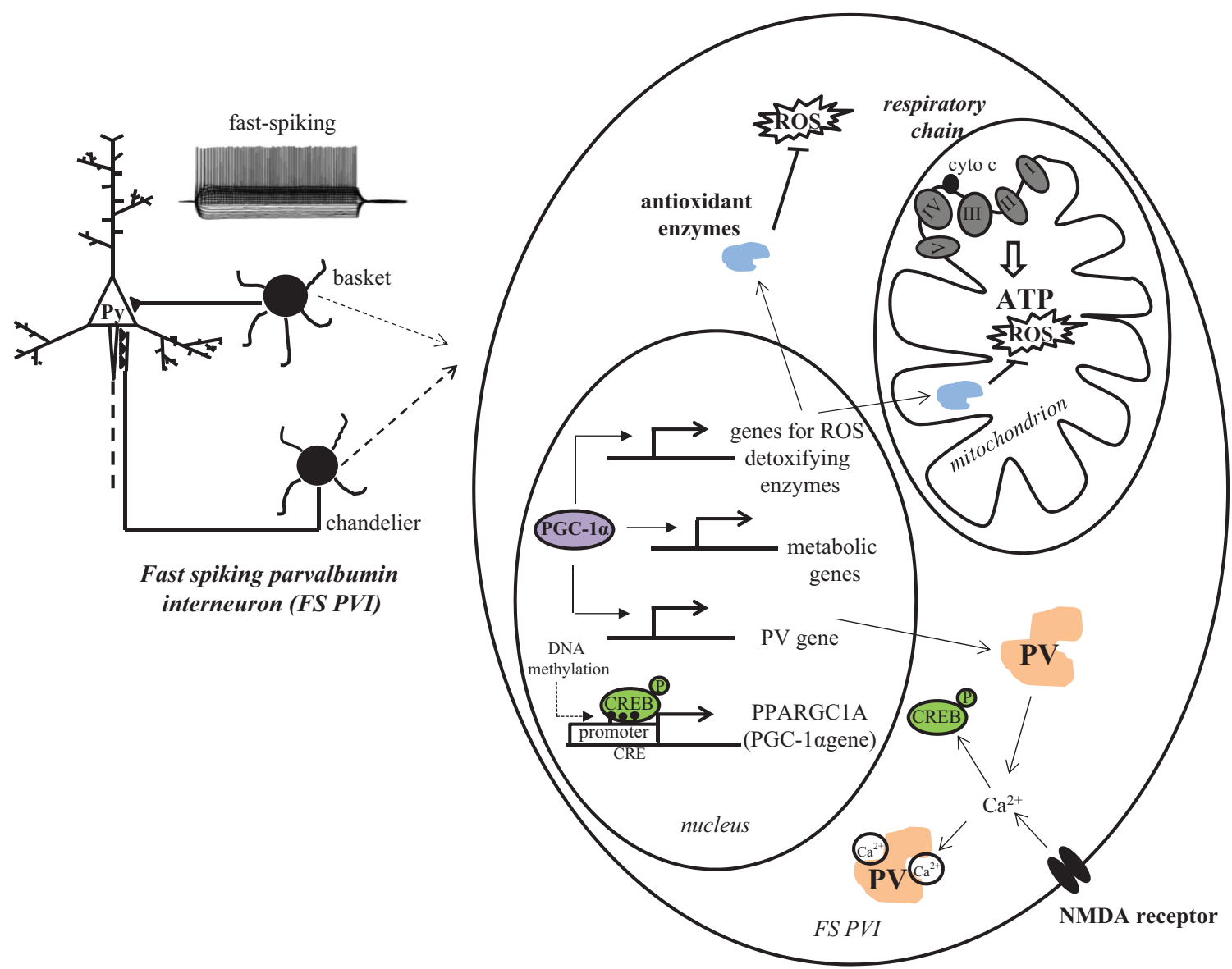

FIGURE 2 | PGC-1 $\alpha$ is a critical contributor to the antioxidant capacity of FS PVIs. The high energy demand of FS PVIs makes them vulnerable to mitochondrial dysfunction and oxidative stress. PGC-1 $\alpha$, a master regulator of transcriptional programs involved in mitochondrial energy metabolism and antioxidant defense, is highly concentrated in PVIs. In concert with other proteins, PGC-1 $\alpha$ increases the transcription of antioxidant enzymes and PV. Transcription of PGC- $1 \alpha$ itself is intracellular $\mathrm{Ca}^{2+}$ influx-dependent and can be regulated by epigenetic modifications.
In the central nervous system, PGC- $1 \alpha$ protein is expressed most highly in GABAergic neurons (Cowell et al., 2007) with a particularly high concentration in cortical PVIs (Jiang et al., 2013). Reductions in PGC- $1 \alpha$ mRNA or protein level and its activity have been implicated in several neurodegenerative diseases, such as Huntington (Cui et al., 2006; Weydt et al., 2006), Alzheimer's (Qin et al., 2009), and Parkinson's Disease (Zheng et al., 2010; Shin et al., 2011). A complete absence of PGC-1 $\alpha$ in mice causes profound motor impairment and spongioform neurodegeneration in the striatum and cortex (Lin et al., 2004) by six weeks of age that is entirely attributable to a loss of PGC$1 \alpha$ in the central nervous system (Lucas et al., 2012). Of note, motor impairments are still observed in PGC- $1 \alpha$ heterozygous mice, albeit to a lesser extent (Lucas et al., 2012); it is possible that the heterozygous mice would provide a better model to investigate the relevance of PGC- $1 \alpha$ reductions for understanding its roles in pathophysiology.

The neuroprotective effect of endogenous PGC- $1 \alpha$ has been explored in multiple different studies. Mice lacking PGC- $1 \alpha$ are more sensitive to neurodegeneration induced by 1-methyl-4-phenyl-1，2，3，6-tetrahydropyridine (MPTP) and kainic acid, and this degeneration was associated with greater levels of stable markers of oxidative damage, such as nitrotyrosylation of proteins and $8-\mathrm{OH}-\mathrm{dG}$ in DNA. Elevation of PGC- $1 \alpha$ levels above those of wild-type nerve cells give an increased resistance to death by the oxidative stressors $\mathrm{H}_{2} \mathrm{O}_{2}$ and paraquat (St-Pierre et al., 2006), and overexpression of PGC- $1 \alpha$ in culture increases mitochondrial density and ATP levels (Wareski et al., 2009), drives the expression of transcripts involved in antioxidant defense, glucose transport, and mitochondrial fusion and protects cells from hydrogen peroxide-induced cell death and caspase- 3 activation (Cowell et al., 2009). In the context of NMDAR activation (Hardingham and Bading, 2010), knock-down of endogenous PGC- $1 \alpha$ mediated by siRNA increases extrasynaptic NMDAR(EX) activity and vulnerability to excitotoxic insults in rat cortical neurons, while exogenous expression of PGC- $1 \alpha$ cDNA results in a neuroprotective reduction of extrasynaptic currents without affecting synaptic NMDAR activity (Puddifoot et al., 2012). 
Interestingly, PGC- $1 \alpha$ protein is selectively localized to interneuron nuclei by the second week of postnatal life in rodent brain (Cowell et al., 2007), although its mRNA and protein are observed in neurons throughout the embryonic forebrain. This temporal pattern of expression coincides with the postnatal developmental switch of GABA from an excitatory to inhibitory neurotransmitter and the developmental induction of PV. In fact, mice lacking PGC- $1 \alpha$ are deficient in PV-IR, without a loss of other interneuron markers such as GAD67, GAD65, calbindin, calretinin, cholescystokinin and somatostatin (Lucas et al., 2010). Changes in mRNA level of the PVI specific potassium channel Kv3.1 were not observed, either, suggesting that FS interneurons are intact in PGC- $1 \alpha$ null mice, just lacking expression of PV protein. Furthermore, overexpression of PGC$1 \alpha$ cDNA in neuroblastoma cells robustly induces transcription of PV promoter, implicating PGC- $1 \alpha$ as a critical factor for the developmental induction of PV gene transcription in cortical PVIs. In support of this hypothesis, we found substantial overlap of PV and PGC- $1 \alpha$ mRNA in the cortex, with almost all PV mRNA-containing cells being PGC- $1 \alpha$ mRNA-positive in S1 cortex and most of the total population of PGC- $1 \alpha$ mRNA positive cells being PV mRNA-positive (Jiang et al., 2013). These observations raise the possibility that PGC- $1 \alpha$ coordinately regulates programs of gene expression for the developmental induction of PV and an increased antioxidant capacity in PVIs (Figure 2).

With this in mind, we investigated whether PGC- $1 \alpha$ mRNA or protein is affected by the developmental deletion of NMDARs in our Ppp1r2-cre/fGluN1 KO mice (Jiang et al., 2013). Cortical PGC- $1 \alpha$ mRNA and protein levels were down-regulated and postnatal social isolation exacerbated the reduction. In addition to a reduction in PV-IR, mutant mice exhibited a reduction in mRNA levels of several key ROS-detoxifying enzymes including CuZnSOD, MnSOD, CAT and Gpx, and an impairment in antioxidant capacity and cortical oxidative stress. All these results suggest that PGC- $1 \alpha$ plays a critical role in PVI antioxidant capacity that could have relevance for the understanding of schizophrenia pathophysiology. While it is currently not known whether PGC-1 $\alpha$ expression is affected in schizophrenia, genetic association studies on chromosome $4 \mathrm{p}$ implicated the PGC- $1 \alpha$ gene locus in bipolar disorder and schizophrenia (Blackwood et al., 1996; Christoforou et al., 2007, 2011). Integration of genetic data across human and murine studies also suggests PGC- $1 \alpha$ as a potential susceptibility gene for anxiety-related disorders (Hettema et al., 2011).

Concerning the potential roles for PGC- $1 \alpha$ in the maintenance of mitochondrial function, there is substantial evidence for mitochondrial dysfunction in schizophrenia. Using ${ }^{31}$ phosphorus magnetic resonance spectroscopy $\left({ }^{31} \mathrm{P}-\mathrm{MRS}\right)$ to measure ATP and phospholipids (Fujimoto et al., 1992; Volz et al., 1997), and positron emission tomography (PET) scans with $\left[{ }^{18} \mathrm{~F}\right]$-fluorodeoxy-glucose (FDG; Buchsbaum and Hazlett, 1998), altered energy metabolism has been observed in cerebral cortex of schizophrenic patients. A significant decrease in mitochondria number and density in the prefrontal cortex and caudate nucleus of postmortem brains of subjects with schizophrenia was observed compared with control subjects (Uranova et al., 2001). A lower number of mitochondria were found in medication- free patients compared with those taking antipsychotics or control medications, suggesting drug treatment normalizes the number of mitochondria (Inuwa et al., 2005). Combining a parallel transcriptomics, proteomics and metabomics approach, Prabakaran et al. (2004) explored the molecular signatures in brain tissue of schizophrenia. Almost half of the altered proteins identified were associated with mitochondrial function and oxidative stress responses. Critical role of PGC- $1 \alpha$ in mitochondrial biogenesis and metabolism highlights it as an interesting candidate for further study in the context of schizophrenia.

\section{POTENTIAL BIOLOGICAL MECHANISMS UNDERLYING CONVERGENCE OF GxE ON PGC-1 $\alpha$}

It is notable in our study that no significant change in PGC$1 \alpha$ mRNA or protein level in Ppp1r2-cre/fGluN1 KO mice was observed until the post-adolescent period (eight week old). Postweaning social isolation exacerbated the reduction of PGC- $1 \alpha$ only in $\mathrm{KO}$ mice. This implicates that PGC- $1 \alpha$, as a master regulator of mitochondria energy metabolism and anti-oxidation, with a selective expression pattern in FS PVI, could be a potential converging factor for GxE. However, the mechanisms by which GxE regulate PGC- $1 \alpha$ transcription and trigger oxidative stress on PVIs remains to be clarified.

\section{Early postnatal NMDAR hypofunction in cortical PVI}

Notably, PGC- $1 \alpha$ transcription and activity itself can be regulated by alterations in intracellular calcium concentrations and the activation of calcium calmodulin-dependent kinase IV (Handschin et al., 2003) that often occur with activation of the NMDAR. In fact, in neurons, transcription of PGC- $1 \alpha$ is activity-dependent (Liang and Wong-Riley, 2006; Meng et al., 2007; Yu and Yang, 2010) and increased by NMDAR activation (Lee et al., 2007; Luo et al., 2009; Liang et al., 2010; Figure 2). Thus, it is not surprising that early postnatal $\mathrm{KO}$ of NMDAR in PVIs is associated with a down-regulation of PGC- $1 \alpha$.

\section{Epigenetic regulation of PGC-1 $\alpha$}

Another mechanism of PGC- $1 \alpha$ regulation that could account for environmental and genetic convergence on PVIs may be the modulation of PGC- $1 \alpha$ transcription and/or activity by epigenetic mechanisms. Increasing evidence suggests that external environmental factors, such as nutritional, chemical, physical, even psychosocial factors can modify gene expression through epigenetic processes (Jirtle and Skinner, 2007). Epigenetics refers to a set of mitotically heritable and reversible changes in gene expression that occur without a change in the genomic DNA sequence. Epigenetic changes have been associated with a number of paradigms involving social behavior in animal models, such as maternal care (Weaver et al., 2004), early life adversity (Murgatroyd et al., 2009), animal models of posttraumatic stress disorder (PTSD; Chertkow-Deutsher et al., 2010) and chronic social defeat (Tsankova et al., 2006).

Furthermore, epigenetic changes in interneuron-specific transcripts have been documented in schizophrenia; a significant reduction of GABAergic protein (GAD67 and reelin) are accompanied by increased methylation of the GAD67 and Reelin 
promoters and increased DNA methyltransferase (DNMT) one in the same interneurons in the cortex of schizophrenic patients (Guidotti et al., 2000; Grayson et al., 2005; Veldic et al., 2005; Huang et al., 2007; Ruzicka et al., 2007). Mill et al. (2008) published the first epigenome-wide study of psychosis using postmortem tissue obtained from frontal cortex of patients with schizophrenia or bipolar disorders. This study enriched the unmethylated fraction of genome DNA and used a CpG island microarray to assay DNA methylation at approximately 12,000 sites across the genome. Their gene-ontology analysis highlights epigenetic disruption to loci involved in mitochondrial function, stress response and brain development.

Recently, another study utilizing genome-wide methylation profiling of blood samples from monozygotic twins discordant for schizophrenia linked aberrant DNA methylation of PGC$1 \alpha$ gene to schizophrenia (Dempster et al., 2011). Indeed, one CRE (CREB binding site) was found in mouse PGC- $1 \alpha$ promoter region and it encompassed a $\mathrm{CpG}$ site (Figure 2). It has been reported that methylation of $\mathrm{CpG}$ in CRE blocked pCREB binding (Iguchi-Ariga and Schaffner, 1989; Sunahori et al., 2009). CREB is an important regulator for PGC- $1 \alpha$ gene transcription (Herzig et al., 2001; St-Pierre et al., 2006). Barrès et al. (2009) provided evidence that PGC-1 $\alpha$ hypermethylation is concomitant with reduced mitochondrial content in type 2 diabetic patients, and links DNMT3B to the acute fatty-acidinduced non-CpG methylation of PGC- $1 \alpha$ promoter. Although studies by Dempster et al. (2011) and others assessed PGC-1 $\alpha$ methylation status in peripheral samples, and the methylation response in peripheral cells may not accurately reflect methylation status in the brain (Provençal et al., 2012), these data suggest that a differential epigenetic response does occur on PGC- $1 \alpha$ in schizophrenic individuals compared with normal subjects. There is also evidence that PGC- $1 \alpha$ gene expression and activity are influenced directly by inhibitors of histone deacetylases (HDACs), enzymes that epigenetically modify histones to block transcription. Overexpression of HDAC5 reduces PGC- $1 \alpha$ in the heart (Czubryt et al., 2003) by blocking the developmental induction of PGC- $1 \alpha$ by myocyte enhancing factor 2 (MEF2), and exposure of neuroblastoma cells to the HDAC inhibitors trichostatin A or valproic acid (a mood stabilizer given as adjunct therapy to schizophrenia patients) increases mRNA level of PGC- $1 \alpha$ and its target gene glucose transporter four (Cowell et al., 2009). Hypoxia exposure itself can cause an increase in the expression of the DNA methylating enzymes DNMT1 and DNMT3b mRNA that is sustained in adulthood and accompanied by increased methylation of the SOD2 promoter (Nanduri et al., 2012); taking into account the role of PGC- $1 \alpha$ in tissue responses to hypoxia (Arany et al., 2008; Zhu et al., 2010; Pino et al., 2012; Zhao et al., 2012), it is attractive to speculate that environmental stimuli can modulate PGC-1 $\alpha$-dependent pathways and PVI antioxidant capacity by epigenetic mechanisms.

Hypothalamic-pituitary-adrenocortical (HPA) hyperactivity by social isolation/stress could involve into PGC- $1 \alpha$ regulation through epigenetic mechanisms as well. Activation of the HPA axis represents a common reaction to many environmental insults, including infection, malnutrition, hypoxia, and psychosocial stress (Oitzl et al., 2010). Most of rodent studies showed that chronic early life social isolation is associated with higher basal levels of glucocorticoids and increased HPA response to acute stressors (Weiss et al., 2004; Chida et al., 2005; Perelló et al., 2006; Ruscio et al., 2007; Williams et al., 2009; Weintraub et al., 2010; Toth et al., 2011). Glucocorticoids have been reported to influence DNA methylation in genes containing glucocorticoid response elements (GREs), such as fkbp5 and tyrosine hydroxylase gene (Lee et al., 2011; Niwa et al., 2013). Studies in early postnatal maternal care/separation have linked epigenetic mechanisms with alteration of genes involved in the regulation of the HPA axis. Early life experience influences DNA methylation state of glucocorticoid receptor (GR) gene in human studies (Oberlander et al., 2008; McGowan et al., 2009; Labonte et al., 2012) and animal models (see review by, Weaver, 2009). Epigenetic-mediated changes in GR could contribute to PGC- $1 \alpha$ alteration. Further studies need to be done to clarify how GxE influence the transcription of PGC- $1 \alpha$ and PV and antioxidant capacity in cortical PVIs.

\section{SUMMARY}

The interaction between genes and environment ( $\mathrm{GxE})$ has been postulated to be critical to trigger the onset of schizophrenia. Epidemiological observations and neuropathological studies all support that schizophrenia is a consequence of abnormal brain development. As an essential player in the generation of gamma oscillations, corticolimbic PVIs have a key role in higher cognitive processing. Considering the evidence for PVI dysfunction in patients with schizophrenia and in various neurodevelopmental animal models, the vulnerability of PVIs during early life development and the mechanisms by which these neurons respond to environmental stimuli are particularly relevant for our understanding of schizophrenia pathophysiology. Here, we presented evidence for a convergence of genetic and environmental factors on oxidative stress in PVIs and suggest that PGC- $1 \alpha$ is a critical regulator of PV transcription and antioxidant capacity in these neurons. The delayed maturation during postnatal period and high energy demanding of FS PVIs make them susceptible to environmental insults, particularly redox imbalance, during early life experience. Oxidative stress could be one of the important mechanisms integrates GxE on PVIs disturbance. PGC- $1 \alpha$, as a master regulator of mitochondrial metabolism, which is highly and selectively expressed in PVIs, could be one of the key factors responsible for the antioxidant capacity of PVIs. Our study using NMDAR hypofunction animal model revealed that redox dysregulation due to a decrease in PGC$1 \alpha$ abundance in cortical parvalbumin interneurons exacerbated schizophrenia-like phenotypes following social isolation stress. This implicates PGC- $1 \alpha$ as a potential converging factor for GxE. Further studies on the impact of GxE on PGC- $1 \alpha$ transcription and function would not only help identify neuropathophysiological mechanism underlying GxE in schizophrenia, but importantly, aid in the development of targeted interventions for this illness.

\section{ACKNOWLEDGMENTS}

This research was supported by the Intramural Research Programs of the NIMH, and K01MH077955-05 (RMC). 


\section{REFERENCES}

Abekawa, T., Ito, K., Nakagawa, S., and Koyama, T. (2007). Prenatal exposure to an NMDA receptor antagonist, MK-801 reduces density of parvalbumin-immunoreactive GABAergic neurons in the medial prefrontal cortex and enhances phencyclidine-induced hyperlocomotion but not behavioral sensitization to methamphetamine in postpubertal rats. Psychopharmacology (Berl) 192, 303-316. doi: 10. 1007/s00213-007-0729-8

Akyol, O., Yanik, M., Elyas, H., Namli, M., Canatan, H., Akin, H., et al. (2005). Association between Ala9Val polymorphism of Mn-SOD gene and schizophrenia. Prog. Neuropsychopharmacol. Biol. Psychiatry 29, 123-131. doi: 10.1016/j.pnpbp. 2004.10.014

Al-Chalabi, B. M., Thanoon, I. A., and Ahmed, F. A. (2009). Potential effect of olanzapine on total antioxidant status and lipid peroxidation in schizophrenic patients. Neuropsychobiology 59, 8-11. doi: 10. 1159/000202823

American Psychiatric Association. (1994). Fourth Diagnostic and Statistical Manual of Mental Disorders (DSM-IV), ed American Psychiatric Association (Washington DC: America Psychiatric Association).

Anderson, S. A., Classey, J. D., Condé, F., Lund, J. S., and Lewis, D. A. (1995). Synchronous development of pyramidal neuron dendritic spines and parvalbuminimmunoreactive chandelier neuron axon terminals in layer III of monkey prefrontal cortex. Neuroscience 67, 7-22. doi: 10.1016/03064522(95)00051-J

Arany, Z., Foo, S. Y., Ma, Y., Ruas, J. L., Bommi-Reddy, A., Girnun, G., et al. (2008). HIF-independent regulation of VEGF and angiogenesis by the transcriptional coactivator PGC-1alpha. Nature 451, 10081012. doi: $10.1038 /$ nature 06613

Ascoli, G. A., Alonso-Nanclares, L., Anderson, S. A., Barrionuevo, G., Benavides-Piccione, R., Burkhalter, A., et al. (2008). Petilla terminology: nomenclature of features of GABAergic interneurons of the cerebral cortex. Nat. Rev. Neurosci. 9, 557-568. doi: 10.1038/nrn2402

Ayhan, Y., Abazyan, B., Nomura, J., Kim, R., Ladenheim, B., Krasnova, I. N., et al. (2011). Differential effects of prenatal and postnatal expressions of mutant human DISC1 on neurobehavioral phenotypes in transgenic mice: evidence for neurodevelopmental origin of major psychiatric disorders. Mol. Psychiatry 16, 293-306. doi: 10.1038/mp. 2009.144

Baar, K., Wende, A. R., Jones, T. E., Marison, M., Nolte, L. A., Chen, M., et al. (2002). Adaptations of skeletal muscle to exercise: rapid increase in the transcriptional coactivator PGC-1. FASEB J. 16, 1879 1886. doi: 10.1096/fj.02-0367com

Barkus, E., and Murray, R. M. (2010). Substance use in adolescence and psychosis: clarifying the relationship. Annu. Rev. Clin. Psychol. 6, 365-389. doi: 10.1146/annurev. clinpsy.121208.131220

Barrès, R., Osler, M. E., Yan, J., Rune, A., Fritz, T., Caidahl, K., et al. (2009). Non-CpG methylation of the PGC-1alpha promoter through DNMT3B controls mitochondrial density. Cell Metab. 10, 189-198. doi: 10.1016/j.cmet.2009.07.011

Basu, A., Lenka, N., Mullick, J., and Avadhani, N. G. (1997). Regulation of murine cytochrome oxidase $\mathrm{Vb}$ gene expression in different tissues and during myogenesis. Role of a YY-1 factor-binding negative enhancer. J. Biol. Chem. 272, 58995908. doi: 10.1074/jbc.272.9.5899

Bayer, T. A., Falkai, P., and Maier, W. (1999). Genetic and non-genetic vulnerability factors in schizophrenia: the basis of the "two hit hypothesis”. J. Psychiatr. Res. 33, 543548. doi: 10.1016/S0022-3956(99) 00039-4

Behrens, M. M., Ali, S. S., Dao, D. N., Lucero, J., Shekhtman, G., Quick, K. L., et al. (2007). Ketamineinduced loss of phenotype of fastspiking interneurons is mediated by NADPH-oxidase. Science 318, 16451647. doi: 10.1126/science.1148045

Behrens, M. M., Ali, S. S., and Dugan, L. L. (2008). Interleukin-6 mediates the increase in NADPH-oxidase in the ketamine model of schizophrenia. J. Neurosci. 28, 13957-13966. doi: 10.1523/JNEUROSCI.4457-08. 2008

Behrens, M. M., and Sejnowski, T. J. (2009). Does schizophrenia arise from oxidative dysregulation of parvalbumin-interneurons in the developing cortex?. Neuropharmacology 57, 193-200. doi: 10.1016/j. neuropharm.2009.06.002

Belforte, J. E., Zsiros, V., Sklar, E. R., Jiang, Z., Yu, G., Li, Y., et al. (2010). Postnatal NMDA receptor ablation in corticolimbic interneurons confers schizophrenia-like phenotypes. Nat. Neurosci. 13, 76-83. doi: 10. 1038/nn.2447

Beloosesky, R., Gayle, D. A., Amidi, F., Nunez, S. E., Babu, J., Desai, M., et al. (2006). N-acetyl-cysteine suppresses amniotic fluid and placenta inflammatory cytokine responses to lipopolysaccharide in rats. Am. J. Obstet. Gynecol. 194, 268-273. doi: 10.1016/j.ajog.2005.06.082

Ben-Ari, Y., Khalilov, I., Represa, A., and Gozlan, H. (2004). Interneurons set the tune of developing networks. Trends Neurosci. 27, 422-427. doi: 10.1016/j.tins.2004.05.002

Ben-Ari, Y., Woodin, M. A., Sernagor, E., Cancedda, L., Vinay, L., Rivera, C., et al. (2012). Refuting the challenges of the developmental shift of polarity of GABA actions: GABA more exciting than ever!. Front. Cell. Neurosci. 6:35. doi: 10.3389/fncel. 2012.00035

Benes, F. M., Vincent, S. L., Alsterberg, G., Bird, E. D., and SanGiovanni, J. P. (1992). Increased GABAA receptor binding in superficial layers of cingulate cortex in schizophrenics. J. Neurosci. 12, 924-929.

Benes, F. M., Vincent, S. L., Marie, A., and Khan, Y. (1996). Up-regulation of GABAA receptor binding on neurons of the prefrontal cortex in schizophrenic subjects. Neuroscience 75, 1021-1031. doi: 10.1016/03064522(96)00328-4

Blackwood, D. H., He, L., Morris, S. W., McLean, A., Whitton, C., Thomson, M., et al. (1996). A locus for bipolar affective disorder on chromosome 4p. Nat. Genet. 12, 427-430. doi: 10. 1038/ng0496-427

Brown, A. S. (2011). The environment and susceptibility to schizophrenia. Prog. Neurobiol. 93, 23-58. doi: 10. 1016/j.pneurobio.2010.09.003

Buchsbaum, M. S., and Hazlett, E. A. (1998). Positron emission tomography studies of abnormal glucose metabolism in schizophrenia. Schizophr. Bull. 24, 343-364. doi: 10.1093/oxfordjournals.schbul. a033331

Buhimschi, I. A., Buhimschi, C. S., and Weiner, C. P. (2003). Protective effect of $\mathrm{N}$-acetylcysteine against fetal death and preterm labor induced by maternal inflammation. Am. J. Obstet. Gynecol. 188, 203-208. doi: 10.1067/mob. 2003.112

Caballero, A., Flores-Barrera, E., Cass, D. K., and Tseng, K. Y. (2013). Differential regulation of parvalbumin and calretinin interneurons in the prefrontal cortex during adolescence. Brain Struct. Funct. doi: 10.1007/s00429-013-0508-8. [Epub ahead of print].

Cabungcal, J. H., Preissmann, D., Delseth, C., Cuénod, M., Do, K. Q., and Schenk, F. (2007). Transitory glutathione deficit during brain development induces cognitive impairment in juvenile and adult rats: relevance to schizophrenia. Neurobiol. Dis. 26, 634-645. doi: 10.1016/j.nbd.2007.03.001

Cabungcal, J. H., Steullet, P., Kraftsik, R., Cuenod, M., and Do, K. Q. (2013a) Early-life insults impair parvalbumin interneurons via oxidative stress: reversal by $\mathrm{N}$ acetylcysteine. Biol. Psychiatry 73, 574-582. doi: 10.1016/j.biopsych. 2012.09.020

Cabungcal, J. H., Steullet, P., Morishita, H., Kraftsik, R., Cuenod, M. Hensch, T. K., et al. (2013b) Perineuronal nets protect fast-spiking interneurons against oxidative stress. Proc. Natl. Acad. Sci. U S A 110, 9130-9135. doi: 10.1073/pnas. 1300454110

Cardin, J. A., Carlén, M., Meletis, K., Knoblich, U., Zhang, F., Deisseroth, K., et al. (2009). Driving fast-spiking cells induces gamma rhythm and controls sensory responses. Nature 459, 663-667. doi: 10.1038/nature08002

Cardno, A. G., and Gottesman, I. I. (2000). Twin studies of schizophrenia: from bow-and-arrow concordances to star wars $\mathrm{Mx}$ and functional genomics. Am. J. Med. Genet. 97, 12-17. doi: 10.1002/(SICI)10968628(200021)97:1<12::AID-AJMG 3>3.0.CO;2-U

Carlson, G. C., Talbot, K., Halene, T. B., Gandal, M. J., Kazi, H. A., Schlosser, L., et al. (2011). Dysbindin-1 mutant mice implicate reduced fast-phasic inhibition as a final common disease mechanism in schizophrenia. Proc. Natl. Acad. Sci. U S A 108, E962-E970. doi: 10. 1073/pnas.1109625108

Carter, J. W., Schulsinger, F., Parnas, J., Cannon, T., and Mednick, S. A. (2002). A multivariate prediction model of schizophrenia. Schizophr. Bull. 28, 649-682. doi: 10.1093/oxfordjournals.schbul. a006971

Chakraborti, A., Gulati, K., Banerjee, B. D., and Ray, A. (2007). Possible involvement of free radicals in the differential neurobehavioral responses to stress in male and female rats. Behav. Brain Res. 179 , 321-325. doi: 10.1016/j.bbr.2007.02. 018

Chattopadhyaya, B., Di Cristo, G., Higashiyama, H., Knott, G. W., Kuhlman, S. J., Welker, E., et al. (2004). Experience and activitydependent maturation of perisomatic GABAergic innervations in primary visual cortex dur- 
ing a postnatal critical period. J. Neurosci. 24, 9598-9611. doi: 10. 1523/JNEUROSCI.1851-04.2004

Chattopadhyaya, B., Di Cristo, G., Wu, C. Z., Knott, G., Kuhlman, S., Fu, Y., et al. (2007). GAD67-mediated GABA synthesis and signaling regulate inhibitory synaptic innervation in the visual cortex. Neuron 54, 889903. doi: 10.1016/j.neuron.2007.05. 015

Chertkow-Deutsher, Y., Cohen, H., Klein, E., and Ben-Shachar, D. (2010). DNA methylation in vulnerability to post-traumatic stress in rats: evidence for the role of the post-synaptic density protein Dlgap2. Int. J. Neuropsychopharmacol. 13, 347-359. doi: 10. 1017/S146114570999071X

Chida, Y., Sudo, N., and Kubo, C. (2005). Social isolation stress exacerbates autoimmune disease in MRL/lpr mice. J. Neuroimmunol 158, 138-144. doi: 10.1016/j. jneuroim.2004.09.002

Cho, R. Y., Konecky, R. O., and Carter, C. S. (2006). Impairments in frontal cortical gamma synchrony and cognitive control in schizophrenia. Proc. Natl. Acad. Sci. U S A 103, 19878-19883. doi: 10. 1073/pnas.0609440103

Christoforou, A., Le Hellard, S., Thomson, P. A., Morris, S. W., Tenesa, A., Pickard, B. S., et al. (2007). Association analysis of the chromosome 4p15-p16 candidate region for bipolar disorder and schizophrenia. Mol. Psychiatry 12, 1011-1025. doi: 10. 1038/sj.mp.4002003

Christoforou, A., McGhee, K. A., Morris, S. W., Thomson, P. A., Anderson, S., McLean, A., et al. (2011). Convergence of linkage, association and GWAS findings for a candidate region for bipolar disorder and schizophrenia on chromosome 4p. Mol. Psychiatry 16, 240-242. doi: 10. 1038/mp.2010.25

Cobos, I., Long, J. E., Thwin, M. T., and Rubenstein, J. L. (2006). Cellular patterns of transcription factor expression in developing cortical interneurons. Cereb. Cortex 1(Suppl. 16), i82-i88. doi: 10. 1093/cercor/bhk003

Condé, F., Lund, J. S., Jacobowitz, D. M., Baimbridge, K. G., and Lewis, D. A. (1994). Local circuit neurons immunoreactive for calretinin, calbindin D-28k or parvalbumin in monkey prefrontal cortex: distribution and morphology. J. Comp. Neurol. 341, 95-116. doi: 10.1002/cne. 903410109

Connors, B. W., and Gutnick, M. J. (1990). Intrinsic firing patterns of diverse neocortical neurons. Trends Neurosci. 13, 99-104. doi: 10. 1016/0166-2236(90)90185-D

Coughlin, J. M., Ishizuka, K., Kano, S. I., Edwards, J. A., Seifuddin, F. T., Shimano, M. A., et al. (2013). Marked reduction of soluble superoxide dismutase-1 (SOD1) in cerebrospinal fluid of patients with recent-onset schizophrenia. Mol. Psychiatry 18, 10-11. doi: 10. 1038/mp.2012.6

Cowell, R. M., Blake, K. R., and Russell, J. W. (2007). Localization of the transcriptional coactivator PGC-1alpha to GABAergic neurons during maturation of the rat brain. J. Comp. Neurol. 502, 1-18. doi: 10. 1002/cne.21211

Cowell, R. M., Talati, P., Blake, K. R., Meador-Woodruff, J. H., and Russell, J. W. (2009). Identification of novel targets for PGC-1alpha and histone deacetylase inhibitors in neuroblastoma cells. Biochem. Biophys. Res. Commun. 379, 578582. doi: 10.1016/j.bbrc.2008. 12.109

Csicsvari, J., Jamieson, B., Wise, K. D., and Buzsáki, G. (2003). Mechanisms of gamma oscillations in the hippocampus of the behaving rat. Neuron 37, 311-322. doi: 10. 1016/s0896-6273(02)01169-8

Cui, L., Jeong, H., Borovecki, F., Parkhurst, C. N., Tanese, N., Krainc, D., et al. (2006). Transcriptional repression of PGC-1alpha by mutant huntingtin leads to mitochondrial dysfunction and neurodegeneration. Cell 127, 59-69. doi: 10.1016/j.cell.2006.09.015

Cunningham, J. T., Rodgers, J. T., Arlow, D. H., Vazquez, F., Mootha, V. K., Puigserver, P., et al. (2007). mTOR controls mitochondrial oxidative function through a YY1-PGC-1alpha transcriptional complex. Nature 450, 736-740. doi: 10.1038/nature06322

Curley, A. A., Arion, D., Volk, D. W., Asafu-Adjei, J. K., Sampson, A. R., Fish, K. N., et al. (2011). Cortical deficits of glutamic acid decarboxylase 67 expression in schizophrenia: clinical, protein, and cell typespecific features. Am. J. Psychiatry 168, 921-929. doi: 10.1176/appi.ajp. 2011.11010052

Czubryt, M. P., McAnally, J., Fishman, G. I., and Olson, E. N. (2003). Regulation of peroxisome proliferatoractivated receptor gamma coactivator 1alpha (PGC-1 alpha) and mitochondrial function by MEF2 and HDAC5. Proc. Natl. Acad. Sci. U S A 100, 1711-1716. doi: 10.1073/pnas. 0337639100
Dadheech, G., Mishra, S., Gautam, S., and Sharma, P. (2008). Evaluation of antioxidant deficit in schizophrenia. Indian J. Psychiatry 50, 16-20. doi: 10.4103/0019-5545. 39753

Dafre, A. L., Arteni, N. S., Siqueira, I. R., and Netto, C. A. (2003). Perturbations in the thiol homeostasis following neonatal cerebral hypoxiaischemia in rats. Neurosci. Lett. 345, 65-68. doi: 10.1016/S03043940(03)00510-X

de Lecea, L., del Río, J. A., and Soriano, E. (1995). Developmental expression of parvalbumin mRNA in the cerebral cortex and hippocampus of the rat. Brain Res. Mol. Brain Res. 32, 1-13. doi: 10.1016/0169328X(95)00056-X

Dell'Anna, E., Geloso, M. C., Magarelli, M., and Molinari, M. (1996). Development of GABA and calcium binding proteins immunoreactivity in the rat hippocampus following neonatal anoxia. Neurosci. Lett. 211, 93-96. doi: 10.1016/03043940(96)12733-6

Dempster, E. L., Pidsley, R., Schalkwyk, L. C., Owens, S., Georgiades, A., Kane, F., et al. (2011). Diseaseassociated epigenetic changes in monozygotic twins discordant for schizophrenia and bipolar disorder. Hum. Mol. Genet. 20, 4786-4796. doi: $10.1093 / \mathrm{hmg} / \mathrm{ddr} 416$

Dietrich-Muszalska, A., Olas, B., Gowacki, R., and Bald, E. (2009). Oxidative/nitrative modifications of plasma proteins and thiols from patients with schizophrenia. $\mathrm{Neu}$ ropsychobiology 59, 1-7. doi: 10. 1159/000202822

Dietrich-Muszalska, A., Olas, B., and Rabe-Jablonska, J. (2005). Oxidative stress in blood platelets from schizophrenic patients. Platelets 16, 386-391. doi: 10. 1080/09537100500128872

Dietrich-Muszalska, A., and Olas, B. (2009a). Isoprostenes as indicators of oxidative stress in schizophrenia. World J. Biol. Psychiatry 10, 27-33. doi: 10.1080/15622970701361263

Dietrich-Muszalska, A., and Olas, B. (2009b). Modifications of blood platelet proteins of patients with schizophrenia. Platelets 20, 90-96. doi: 10.1080/09537100802641499

Dityatev, A., Brückner, G., Dityateva, G., Grosche, J., Kleene, R., Schachner, M., et al. (2007). Activity-dependent formation and functions of chondroitin sulfate-rich extracellular matrix of perineuronal nets. Dev. Neurobiol. 67, 570-588. doi: 10.1002/dneu. 20361
Do, K. Q., Cabungcal, J. H., Frank, A., Steullet, P., and Cuenod, M. (2009). Redox dysregulation, neurodevelopment, and schizophrenia. Curr. Opin. Neurobiol. 19, 220-230. doi: 10.1016/j.conb.2009.05.001

Do, K. Q., Trabesinger, A. H., KirstenKrüger, M., Lauer, C. J., Dydak, U., Hell, D., et al. (2000). Schizophrenia: glutathione deficit in cerebrospinal fluid and prefrontal cortex in vivo. Eur. J. Neurosci. 12, 3721-3728. doi: 10.1046/j. 1460-9568.2000.00229.x

Doischer, D., Hosp, J. A., Yanagawa, Y., Obata, K., Jonas, P., Vida, I., et al. (2008). Postnatal differentiation of basket cells from slow to fast signaling devices. J. Neurosci. 28, $12956-$ 12968. doi: 10.1523/JNEUROSCI. 2890-08.2008

Drews, E., Otte, D. M., and Zimmer, A. (2012). Involvement of the primate specific gene G72 in schizophrenia: from genetic studies to pathomechanisms. Neurosci. Biobehav. Rev. doi: 10.1016/j.neubiorev.2012. 10.009. [Epub ahead of print].

Du, J., Zhang, L., Weiser, M., Rudy, B., and McBain, C. J. (1996). Developmental expression and functional characterization of the potassium-channel subunit Kv3.1b in parvalbumin-containing interneurons of the rat hippocampus. J. Neurosci. 16, 506-518.

Ducharme, G., Lowe, G. C., Goutagny, R., and Williams, S. (2012). Early alterations in hippocampal circuitry and theta rhythm generation in a mouse model of prenatal infection: implications for schizophrenia. PLoS One 7:e29754. doi: 10. 1371/journal.pone.0029754

Eichner, L. J., and Giguère, V. (2011). Estrogen related receptors (ERRs): a new dawn in transcriptional control of mitochondrial gene networks. Mitochondrion 11, 544-552. doi: 10. 1016/j.mito.2011.03.121

Elvevåg, B., and Goldberg, T. E. (2000). Cognitive impairment in schizophrenia is the core of the disorder. Crit. Rev. Neurobiol. 14, 1-21. doi: 10.1615/CritRevNeurobiol.v14. i1.10

Erickson, S. L., and Lewis, D. A. (2002). Postnatal development of parvalbumin- and GABA transporter-immunoreactive axon terminals in monkey prefrontal cortex. J. Comp. Neurol. 448, 186-202. doi: 10.1002/cne.10249

Fagel, D. M., Ganat, Y., Cheng, E., Silbereis, J., Ohkubo, Y., Ment, L. R., et al. (2009). Fgfrl is required for cortical regeneration and repair after perinatal 
hypoxia. J. Neurosci. 29, 1202-1211. doi: 10.1523/JNEUROSCI.4516-08. 2009

Fano, S., Behrens, C. J., and Heinemann, U. (2007). Hypoxia suppresses kainate-induced gammaoscillations in rat hippocampal slices. Neuroreport 18, 1827-1831. doi: $\quad 10.1097 /$ WNR.0b013e3282f $13 \mathrm{e} 4 \mathrm{f}$

Feoli, A. M., Siqueira, I., Almeida, L. M., Tramontina, A. C., Battu, C., Wofchuk, S. T., et al. (2006a). Brain glutathione content and glutamate uptake are reduced in rats exposed to pre- and postnatal protein malnutrition. J. Nutr. 136, 2357-2361.

Feoli, A. M., Siqueira, I. R., Almeida, L., Tramontina, A. C., Vanzella, C., Sbaraini, S., et al. (2006b). Effects of protein malnutrition on oxidative status in rat brain. Nutrition 22, 160-165. doi: 10.1016/j.nut.2005. 06.007

Filipovic, D., Zlatkovic, J., Gass, P., and Inta, D. (2013). The differential effects of acute vs chronic stress and their combination on hippocampal parvalbumin and inducible heat shock protein 70 expression. $\mathrm{Neu}$ roscience 236, 47-54. doi: 10.1016/j. neuroscience.2013.01.033

Fisahn, A., Neddens, J., Yan, L., and Buonanno, A. (2009). Neuregulin-1 modulates hippocampal gamma oscillations: implications for schizophrenia. Cereb. Cortex 19, 612-618. doi: 10.1093/cercor/bhn107

Fisher, F. M., Kleiner, S., Douris, N., Fox, E. C., Mepani, R. J., Verdeguer, F., et al. (2012). FGF21 regulates PGC- $1 \alpha$ and browning of white adipose tissues in adaptive thermogenesis. Genes Dev. 26, 271-281. doi: 10.1101/gad.177857.111

Ford, J. M., Roach, B. J., Faustman, W. O., and Mathalon, D. H. (2007). Synch before you speak: auditory hallucinations in schizophrenia. Am. J. Psychiatry 164, 458-466. doi: 10.1176/appi.ajp.164.3.458

Ford, J. M., Roach, B. J., Faustman, W. O., and Mathalon, D. H. (2008). Out-of-synch and out-of-sorts: dysfunction of motor-sensory communication in schizophrenia. Biol. Psychiatry 63, 736-743. doi: 10. 1016/j.biopsych.2007.09.013

Fowles, D. C. (1992). Schizophrenia: diathesis-stress revisited. Аnпи. Rev. Psychol. 43, 303-336. doi: 10. 1146/annurev.ps.43.020192.001511

François, J., Ferrandon, A., Koning, E., Angst, M. J., Sandner, G., Nehlig, A., et al. (2009). Selective reorganization of GABAergic transmission in neonatal ventral hippocampallesioned rats. Int. J. Neuropsy- chopharmacol. 12, 1097-1110. doi: 10.1017/S1461145709009985

Fries, P., Reynolds, J. H., Rorie, A. E., and Desimone, R. (2001). Modulation of oscillatory neuronal synchronization by selective visual attention. Science 291, 1560-1563. doi: 10.1126/science. 1055465

Fries, P., Womelsdorf, T., Oostenveld, R., and Desimone, R. (2008). The effects of visual stimulation and selective visual attention on rhythmic neuronal synchronization in macaque area $\mathrm{V} 4 . \mathrm{J}$. Neurosci. 28, 4823-4835. doi: 10. 1523/JNEUROSCI.4499-07.2008

Fujimoto, T., Nakano, T., Takano, T., Hokazono, Y., Asakura, T., Tsuji, T., et al. (1992). Study of chronic schizophrenics using 31P magnetic resonance chemical shift imaging. Acta Psychiatr. Scand. 86, 455-462. doi: $\quad 10.1111 /$ j.1600-0447.1992. tb03297.x

Fung, S. J., Webster, M. J., Sivagnanasundaram, S., Duncan, C., Elashoff, M., and Weickert, C. S. (2010). Expression of interneuron markers in the dorsolateral prefrontal cortex of the developing human and in schizophrenia. Am. J. Psychiatry 167, 1479-1488. doi: 10.1176/appi. ajp.2010.09060784

Galarreta, M., and Hestrin, S. (1999). A network of fast-spiking cells in the neocortex connected by electrical synapses. Nature 402, 72-75.

Gallinat, J., Winterer, G., Herrmann, C. S., and Senkowski, D. (2004). Reduced oscillatory gammaband responses in unmedicated schizophrenic patients indicate impaired frontal network processing. Clin. Neurophysiol. 115, 1863-1874. doi: 10.1016/j.clinph. 2004.03.013

Gastambide, F., Cotel, M. C., Gilmour, G., O'Neill, M. J., Robbins, T. W., Tricklebank, M. D., et al. (2012). Selective remediation of reversal learning deficits in the neurodevelopmental MAM model of schizophrenia by a novel mGlu5 positive allosteric modulator. $\mathrm{Neu}$ ropsychopharmacology 37, 10571066. doi: 10.1038/npp.2011.298

Gawryluk, J. W., Wang, J. F., Andreazza, A. C., Shao, L., and Young, L. T. (2011). Decreased levels of glutathione, the major brain antioxidant, in post-mortem prefrontal cortex from patients with psychiatric disorders. Int. J. Neuropsychopharmacol. 14, 123-130. doi: 10.1017/S1461145710000805

Gerstein, M., Huleihel, M., Mane, R., Stilman, M., Kashtuzki, I., Hallak, M., et al. (2005). Remod- eling of hippocampal GABAergic system in adult offspring after maternal hypoxia and magnesium sulfate load: immunohistochemical study. Exp. Neurol. 196, 18-29. doi: $\quad 10.1016 /$ j.expneurol.2005. 06.019

Giampà, C., DeMarch, Z., D’Angelo, V., Morello, M., Martorana, A., Sancesario, G., et al. (2006). Striatal modulation of cAMP-responseelement-binding protein (CREB) after excitotoxic lesions: implications with neuronal vulnerability in Huntington's disease. Eur. J. Neurosci. 23, 11-20. doi: 10.1111/j. 1460-9568.2005.04545.x

Gibson, J. R., Beierlein, M., and Connors, B. W. (1999). Two networks of electrically coupled inhibitory neurons in neocortex. Nature 402, 75-79. doi: 10.1038/47035

Gibson, C. L., and Clowry, G. J. (2003). The effect on motor cortical neuronal development of focal lesions to the sub-cortical white matter in the neonatal rat: a model for periventricular leukomalacia. Int. J. Dev. Neurosci. 21, 171-182. doi: 10. 1016/S0736-5748(03)00041-8

Goldberg, E. M., Clark, B. D., Zagha, E., Nahmani, M., Erisir, A., Rudy, B., et al. (2008). K+ channels at the axon initial segment dampen near-threshold excitability of neocortical fast-spiking GABAergic interneurons. Neuron 58, 387-400. doi: 10.1016/j.neuron.2008.03.003

Goldberg, E. M., Jeong, H. Y., Kruglikov, I., Tremblay, R., Lazarenko, R. M., Rudy, B., et al. (2011). Rapid developmental maturation of neocortical FS cell intrinsic excitability. Cereb. Cortex 21, 666-682. doi: 10. 1093/cercor/bhq138

Goldshmit, Y., Erlich, S., and PinkasKramarski, R. (2001). Neuregulin rescues PC12-ErbB4 cells from cell death induced by $\mathrm{H}(2) \mathrm{O}(2)$. Regulation of reactive oxygen species levels by phosphatidylinositol 3-kinase. J. Biol. Chem. 276, 46379-46385. doi: 10.1074/jbc.m105637200

Gottesman, I. I., and Shields, J. (1976). A critical review of recent adoption, twin, and family studies of schizophrenia: behavioral genetics perspectives. Schizophr. Bull. 2, 360401. doi: 10.1093/schbul/2.3.402

Grayson, D. R., Jia, X., Chen, Y., Sharma, R. P., Mitchell, C. P., Guidotti, A., et al. (2005). Reelin promoter hypermethylation in schizophrenia. Proc. Natl. Acad. Sci. U S A 102, 9341-9346. doi: 10. 1073/pnas.0503736102

Grieco, T. M., and Raman, I. M. (2004). Production of resurgent current in NaV1.6-null purkinje neurons by slowing sodium channel inactivation with betapompilidotoxin. J. Neurosci. 24, 3542. doi: 10.1523/JNEUROSCI.380703.2004

Grieco, T. M., Malhotra, J. D., Chen, C., Isom, L. L., and Raman, I. M. (2005). Open-channel block by the cytoplasmic tail of sodium channel beta4 as a mechanism for resurgent sodium current. Neuron 45, 233-244. doi: 10.1016/j.neuron. 2004.12.035

Guan, J., Bennet, T. L., George, S., Waldvogel, H. J., Faull, R. L., Gluckman, P. D., et al. (2000). Selective neuroprotective effects with insulin-like growth factor-1 in phenotypic striatal neurons following ischemic brain injury in fetal sheep. Neuroscience 95, 831-839. doi: 10. 1016/S0306-4522(99)00456-X

Guidotti, A., Auta, J., Davis, J. M., Di-Giorgi-Gerevini, V., Dwivedi, Y., Grayson, D. R., et al. (2000). Decrease in reelin and glutamic acid decarboxylase67 (GAD67) expression in schizophrenia and bipolar disorder: a postmortem brain study. Arch. Gen. Psychiatry 57, 1061-1069. doi: 10.1001/archpsyc.57.11.1061

Gulyás, A. I., Buzsáki, G., Freund, T. F., and Hirase, H. (2006). Populations of hippocampal inhibitory neurons express different levels of cytochrome c. Eur. J. Neurosci. 23, 2581-2594. doi: 10.1111/j. 1460-9568.2006.04814.x

Gulyás, A. I., Megías, M., Emri, Z., and Freund, T. F. (1999). Total number and ratio of excitatory and inhibitory synapses converging onto single interneurons of different types in the CAl area of the rat hippocampus. J. Neurosci. 19, 10082-10097.

Gysin, R., Kraftsik, R., Boulat, O., Bovet, P., Conus, P., Comte-Krieger, E., et al. (2011). Genetic dysregulation of glutathione synthesis predicts alteration of plasma thiol redox status in schizophrenia. Antioxid. Redox Signal. 15, 2003 2010. doi: 10.1089/ars.2010.3463

Gysin, R., Kraftsik, R., Sandell, J., Bovet, P., Chappuis, C., Conus, P., et al. (2007). Impaired glutathione synthesis in schizophrenia: convergent genetic and functional evidence. Proc. Natl. Acad. Sci. U S A 104, 16621-16626. doi: 10. 1073/pnas.0706778104

Haenschel, C., Bittner, R. A., Waltz, J., Haertling, F., Wibral, M., Singer, W., et al. (2009). Cortical oscillatory activity is critical for working memory as revealed by deficits 
in early-onset schizophrenia. J. Neurosci. 29, 9481-9489. doi: 10. 1523/JNEUROSCI.1428-09.2009

Hájos, N., Ellender, T. J., Zemankovics, R., Mann, E. O., Exley, R., Cragg, S. J., et al. (2009). Maintaining network activity in submerged hippocampal slices: importance of oxygen supply. Eur. J. Neurosci. 29, 319-327. doi: 10.1111/j.1460-9568. 2008.06577.x

Hájos, N., Pálhalmi, J., Mann, E. O., Németh, B., Paulsen, O., and Freund, T. F. (2004). Spike timing of distinct types of GABAergic interneuron during hippocampal gamma oscillations in vitro. $J$. Neurosci. 24, 9127-9137. doi: 10. 1523/JNEUROSCI.2113-04.2004

Handschin, C., Rhee, J., Lin, J., Tarr, P. T., and Spiegelman, B. M. (2003). An autoregulatory loop controls peroxisome proliferator-activated receptor gamma coactivator lalpha expression in muscle. Proc. Natl. Acad. Sci. U S A 100, 7111-7116. doi: 10.1073/pnas. 1232352100

Handschin, C., Lin, J., Rhee, J., Peyer, A. K., Chin, S., Wu, P. H., et al. (2005). Nutritional regulation of hepatic heme biosynthesis and porphyria through PGC-1alpha. Cell 122, 505515. doi: 10.1016/j.cell.2005.06. 040

Handschin, C., and Spiegelman, B. M. (2008). The role of exercise and PGClalpha in inflammation and chronic disease. Nature 454, 463-469. doi: 10.1038/nature07206

Hardingham, G. E., and Bading, H. (2010). Synaptic versus extrasynaptic NMDA receptor signalling: implications for neurodegenerative disorders. Nat. Rev. Neurosci. 11, 682-696. doi: 10.1038/nrn2911

Harte, M. K., Powell, S. B., Swerdlow, N. R., Geyer, M. A., and Reynolds, G. P. (2007). Deficits in parvalbumin and calbindin immunoreactive cells in the hippocampus of isolation reared rats. J. Neural Transm. 114, 893-898. doi: 10.1007/s00702-007-0627-6

Hashimoto, T., Bazmi, H. H., Mirnics, K., Wu, Q., Sampson, A. R., and Lewis, D. A. (2008). Conserved regional patterns of GABA-related transcript expression in the neocortex of subjects with schizophrenia. Am. J. Psychiatry 165, 479-489. doi: 10.1176/appi.ajp. 2007.07081223

Hashimoto, T., Bergen, S. E., Nguyen, Q. L., Xu, B., Monteggia, L. M., Pierri, J. N., et al. (2005). Relationship of brain-derived neurotrophic factor and its receptor TrkB to altered inhibitory pre- frontal circuitry in schizophrenia. J. Neurosci. 25, 372-383. doi: 10. 1523/JNEUROSCI.4035-04.2005

Hashimoto, T., Volk, D. W., Eggan, S. M., Mirnics, K., Pierri, J. N., Sun, Z., et al. (2003). Gene expression deficits in a subclass of GABA neurons in the prefrontal cortex of subjects with schizophrenia. $J$. Neurosci. 23, 6315-6326.

Herzig, S., Long, F., Jhala, U. S., Hedrick, S., Quinn, R., Bauer, A., et al. (2001). CREB regulates hepatic gluconeogenesis through the coactivator PGC-1. Nature 413, 179-183. doi: 10.1038/35098123

Hettema, J. M., Webb, B. T., Guo, A. Y., Zhao, Z., Maher, B. S., Chen, X., et al. (2011). Prioritization and association analysis of murine-derived candidate genes in anxiety-spectrum disorders. Biol. Psychiatry 70, 888-896. doi: 10. 1016/j.biopsych.2011.07.012

Hikida, T., Jaaro-Peled, H., Seshadri, S., Oishi, K., Hookway, C., Kong, S., et al. (2007). Dominant-negative DISC1 transgenic mice display schizophrenia-associated phenotypes detected by measures translatable to humans. Proc. Natl. Acad. Sci. U S A 104, 14501-14506. doi: $10.1073 /$ pnas. 0704774104

Howard, M. W., Rizzuto, D. S., Caplan, J. B., Madsen, J. R., Lisman, J., Aschenbrenner-Scheibe, R., et al. (2003). Gamma oscillations correlate with working memory load in humans. Cereb Cortex 13, 1369 1374. doi: 10.1093/cercor/bhg084

Huang, H. S., Matevossian, A., Whittle, C., Kim, S. Y., Schumacher, A., Baker, S. P., et al. (2007). Prefrontal dysfunction in schizophrenia involves mixed-lineage leukemia 1-regulated histone methylation at GABAergic gene promoters. J. Neurosci. 27, 11254-11262. doi: 10. 1523/JNEUROSCI.3272-07.2007

Huang, Z. J., Kirkwood, A., Pizzorusso, T., Porciatti, V., Morales, B., Bear, M. F., et al. (1999). BDNF regulates the maturation of inhibition and the critical period of plasticity in mouse visual cortex. Cell 98, 739755. doi: 10.1016/S0092-8674(00) 81509-3

Huchzermeyer, C., Albus, K., Gabriel, H. J., Otáhal, J., Taubenberger, N., Heinemann, U., et al. (2008). Gamma oscillations and spontaneous network activity in the hippocampus are highly sensitive to decreases in $\mathrm{pO} 2$ and concomitant changes in mitochondrial redox state. J. Neurosci. 28, 1153-1162. doi: 10.1523/JNEUROSCI.4105-07. 2008
Iguchi-Ariga, S. M., and Schaffner, W. (1989). CpG methylation of the cAMP-responsive enhancer/ promoter sequence TGACGTCA abolishes specific factor binding as well as transcriptional activation. Genes Dev. 3, 612-619. doi: 10. 1101/gad.3.5.612

Ingason, A., Rujescu, D., Cichon, S., Sigurdsson, E., Sigmundsson, T., Pietiläinen, O. P., et al. (2011). Copy number variations of chromosome 16 p13.1 region associated with schizophrenia. Mol. Psychiatry 16, 17-25. doi: 10.1038/mp.2009.101

Ingram, R. E., and Luxton, D. D. (2005). "vulnerability-stress models," in Development of Psychopathology: A Vulnerability-Stress Perspective, eds B. L. Hankin and J. R. Z. Abela (Thousand Oaks, CA, US: Sage Publications, Inc), 32-46. $\mathrm{x}$, $510 \mathrm{pp}$.

Insel, T. R. (2010). Rethinking schizophrenia. Nature 468, 187-193. doi: 10.1038/nature09552

Inuwa, I. M., Peet, M., and Williams, M. A. (2005). QSAR modeling and transmission electron microscopy stereology of altered mitochondrial ultrastructure of white blood cells in patients diagnosed as schizophrenic and treated with antipsychotic drugs. Biotech. Histochem. 80, 133-137. doi: 10 . 1080/10520290500303349

Itami, C., Kimura, F., and Nakamura, S. (2007). Brain-derived neurotrophic factor regulates the maturation of layer 4 fast-spiking cells after the second postnatal week in the developing barrel cortex. J. Neurosci. 27, 2241-2252. doi: $\quad$ 10.1523/jneurosci.3345-06. 2007

Jenkins, T. A., Harte, M. K., Stenson, G., and Reynolds, G. P. (2009). Neonatal lipopolysaccharide induces pathological changes in parvalbumin immunoreactivity in the hippocampus of the rat. Behav. Brain Res. 205, 355-359. doi: 10. 1016/j.bbr.2009.07.014

Ji, Y., Yang, F., Papaleo, F., Wang, H. X., Gao, W. J., Weinberger, D. R., et al. (2009). Role of dysbindin in dopamine receptor trafficking and cortical GABA function. Proc. Natl. Acad. Sci. U S A 106, 19593-19598. doi: $10.1073 /$ pnas. 0904289106

Jiang, Z., Rompala, G. R., Zhang, S., Cowell, R. M., and Nakazawa, K. (2013). Social isolation exacerbates schizophrenia-like phenotypes via oxidative stress in cortical interneurons. Biol. Psychiatry 73, 1024-1034. doi: 10.1016/j.biopsych.2012.12. 004
Jiao, Y., Zhang, C., Yanagawa, Y., and Sun, Q. Q. (2006). Major effects of sensory experiences on the neocortical inhibitory circuits. $J$. Neurosci. 26, 8691-8701. doi: 10 1523/jneurosci.2478-06.2006

Jirtle, R. L., and Skinner, M. K. (2007). Environmental epigenomics and disease susceptibility. Nat. Rev. Genet. 8, 253-262. doi: 10. 1038/nrg2045

Kaneko, Y. S., Ota, A., Nakashima, A., Mori, K., Nagatsu, I., Nagatsu, T., et al. (2012). Regulation of oxidative stress in long-lived lipopolysaccharide-activated microglia. Clin. Exp. Pharmacol. Physiol. 39, 599-607. doi: 10. 1111/j.1440-1681.2012.05716.x

Kann, O., Huchzermeyer, C., Kovács, R., Wirtz, S., and Schuelke, M. (2011). Gamma oscillations in the hippocampus require high complex I gene expression and strong functional performance of mitochondria. Brain 134(Pt 2):345-358. doi: 10.1093/brain/awq333

Keshavan, M. S. (1999). Development, disease and degeneration in schizophrenia: a unitary pathophysiological model. J. Psychiatr. Res. 33, 513-521. doi: 10.1016/s00223956(99)00033-3

Krishnan, N., Dickman, M. B., and Becker, D. F. (2008). Proline modulates the intracellular redox environment and protects mammalian cells against oxidative stress. Free Radic. Biol. Med. 44, 671-681. doi: 10. 1016/j.freeradbiomed.2007.10.054

Kulak, A., Cuenod, M., and Do, K. Q. (2012). Behavioral phenotyping of glutathione-deficient mice: relevance to schizophrenia and bipolar disorder. Behav. Brain Res. 226, 563 570. doi: 10.1016/j.bbr.2011.10.020

Labonte, B., Yerko, V., Gross, J., Mechawar, N., Meaney, M. J., Szyf, M., et al. (2012). Differential glucocorticoid receptor exon $1(\mathrm{~B})$, $1(\mathrm{C})$, and $1(\mathrm{H})$ expression and methylation in suicide completers with a history of childhood abuse. Biol. Psychiatry 72, 41-48. doi: 10. 1016/j.biopsych.2012.01.034

Lanté, F., Meunier, J., Guiramand, J., Maurice, T., Cavalier, M., de Jesus Ferreira, M. C., et al. (2007). Neurodevelopmental damage after prenatal infection: role of oxidative stress in the fetal brain. Free Radic. Biol. Med. 42, 1231-1245. doi: 10 . 1016/j.freeradbiomed.2007.01.027

Lapointe, N., St-Hilaire, M., Martinoli, M. G., Blanchet, J., Gould, P., Rouillard, C., et al. (2004). Rotenone induces non-specific central nervous system and systemic toxicity. 
FASEB J. 18, 717-719. doi: 10. 1096/fj.03-0677fje

Lee, R. S., Tamashiro, K. L., Yang, X., Purcell, R. H., Huo, Y., Rongione, M., et al. (2011). A measure of glucocorticoid load provided by DNA methylation of Fkbp5 in mice. Psychopharmacology (Berl) 218, 303-312. doi: 10.1007/s00213-0112307-3

Lee, T. Y., Tsai, K. L., Lee, W. S., and Hsu, C. (2007). The molecular events occur during MK-801induced cytochrome oxidase subunit II down-regulation in GT1-7 cells. J. Mol. Endocrinol. 39, 53-66. doi: 10.1677/jme.1.00002

Levin, S. I., Khaliq, Z. M., Aman, T. K., Grieco, T. M., Kearney, J. A., Raman, I. M., et al. (2006). Impaired motor function in mice with cell-specific knockout of sodium channel Scn8a (NaV1.6) in cerebellar purkinje neurons and granule cells. $\mathrm{J}$. $\mathrm{Neu}$ rophysiol. 96, 785-793. doi: 10. 1152/jn.01193.2005

Liang, H. L., Dhar, S. S., and WongRiley, M. T. (2010). p38 mitogenactivated protein kinase and calcium channels mediate signaling in depolarization-induced activation of peroxisome proliferator-activated receptor gamma coactivator1alpha in neurons. J. Neurosci. Res. 88, 640-649. doi: 10.1002/jnr. 22222

Liang, H. L., and Wong-Riley, M. T. (2006). Activity-dependent regulation of nuclear respiratory factor-1, nuclear respiratory factor-2, and peroxisome proliferator-activated receptor gamma coactivator-1 in neurons. Neuroreport 17, 401-405. doi: 10.1097/01.wnr.0000204980. 98876.11

Lichtenstein, P., Yip, B. H., Björk, C., Pawitan, Y., Cannon, T. D., Sullivan, P. F., et al. (2009). Common genetic determinants of schizophrenia and bipolar disorder in Swedish families: a population-based study. Lancet 373, 234-239. doi: 10. 1016/S0140-6736(09)60072-6

Lin, J., Wu, P. H., Tarr, P. T., Lindenberg, K. S., St-Pierre, J., Zhang, C. Y., et al. (2004). Defects in adaptive energy metabolism with CNS-linked hyperactivity in PGC1alpha null mice. Cell 119, 121-135. doi: 10.1016/j.cell.2004.09.013

Liodis, P., Denaxa, M., Grigoriou, M., Akufo-Addo, C., Yanagawa, Y., Pachnis, V., et al. (2007). Lhx6 activity is required for the normal migration and specification of cortical interneuron subtypes. $J$. Neurosci. 27, 3078-3089. doi: 10. 1523/jneurosci.3055-06.2007
Lodge, D. J., Behrens, M. M., and Grace, A. A. (2009). A loss of parvalbumin-containing interneurons is associated with diminished oscillatory activity in an animal model of schizophrenia. J. Neurosci. 29, 2344-2354. doi: 10. 1523/JNEUROSCI.5419-08.2009

Lucas, E. K., Markwardt, S. J., Gupta, S., Meador-Woodruff, J. H., Lin, J. D., Overstreet-Wadiche, L., et al. (2010). Parvalbumin deficiency and GABAergic dysfunction in mice lacking PGC-1 $\alpha$. J. Neurosci. 30, 7227-7235. doi: 10.1523/jneurosci. 0698-10.2010

Lucas, E. K., Dougherty, S. E., McMeekin, L. J., Trinh, A. T., Reid, C. S., and Cowell, R. M. (2012). Developmental alterations in motor coordination and medium spiny neuron markers in mice lacking pgc- $1 \alpha$. PLoS One 7:e42878. doi: 10.1371/journal.pone.0042878

Luo, Y., Zhu, W., Jia, J., Zhang, C., and $\mathrm{Xu}, \mathrm{Y}$. (2009). NMDA receptor dependent PGC-1alpha up-regulation protects the cortical neuron against oxygen-glucose deprivation/reperfusion injury. $J$. Mol. Neurosci. 39, 262-268. doi: 10. 1007/s12031-009-9196-5

Madrazo, J. A., and Kelly, D. P. (2008). The PPAR trio: regulators of myocardial energy metabolism in health and disease. J. Mol. Cell. Cardiol. 44, 968-975. doi: 10.1016/j. yjmcc. 2008.03.021

Madrigal, J. L., Olivenza, R., Moro, M. A., Lizasoain, I., Lorenzo, P., Rodrigo, J., et al. (2001). Glutathione depletion, lipid peroxidation and mitochondrial dysfunction are induced by chronic stress in rat brain. Neuropsychopharmacology 24, 420-429. doi: 10.1016/s0893$133 \times(00) 00208-6$

Mahadik, S. P., Mukherjee, S., Scheffer, R., Correnti, E. E., and Mahadik, J. S. (1998). Elevated plasma lipid peroxides at the onset of nonaffective psychosis. Biol. Psychiatry 43, 674679. doi: 10.1016/s0006-3223(97) 00282-5

Mann, E. O., Suckling, J. M., Hajos, N., Greenfield, S. A., and Paulsen, O. (2005). Perisomatic feedback inhibition underlies cholinergically induced fast network oscillations in the rat hippocampus in vitro. Neuron 45, 105-117. doi: 10.1016/j. neuron.2004.12.016

Marchbanks, R. M., Ryan, M., Day, I. N., Owen, M., McGuffin, P., and Whatley, S. A. (2003). A mitochondrial DNA sequence variant associated with schizophrenia and oxidative stress. Schizophr. Res. 65,
33-38. doi: 10.1016/s0920-9964(03) 00011-2

Markram, H., Toledo-Rodriguez, M., Wang, Y., Gupta, A., Silberberg, G., and $\mathrm{Wu}, \mathrm{C.}$ (2004). Interneurons of the neocortical inhibitory system. Nat. Rev. Neurosci. 5, 793-807. doi: 10.1038/nrn1519

McCarthy, S. E., Makarov, V., Kirov, G., Addington, A. M., McClellan, J., Yoon, S., et al. (2009). Microduplications of $16 \mathrm{p} 11.2$ are associated with schizophrenia. Nat. Genet. 41, 1223-1227. doi: 10.1038/ng.474

McCreadie, R. G., MacDonald, E., Wiles, D., Campbell, G., and Paterson, J. R. (1995). The nithsdale schizophrenia surveys. XIV: plasma lipid peroxide and serum vitamin $\mathrm{E}$ levels in patients with and without tardive dyskinesia, and in normal subjects. Br. J. Psychiatry 167, 610-617.

McGowan, P. O., Sasaki, A., D’Alessio, A. C., Dymov, S., Labonté, B., Szyf, M., et al. (2009). Epigenetic regulation of the glucocorticoid receptor in human brain associates with childhood abuse. Nat. Neurosci. 12, 342-348. doi: 10.1038/nn.2270

Meade, C. A., Figueredo-Cardenas, G., Fusco, F., Nowak TS, Jr., Pulsinelli, W. A., Reiner, A., et al. (2000). Transient global ischemia in rats yields striatal projection neuron and interneuron loss resembling that in Huntington's disease. Exp. Neurol. 166, 307-323. doi: 10.1006/exnr. 2000.7530

Mellios, N., Huang, H. S., Baker, S. P., Galdzicka, M., Ginns, E., and Akbarian, S. (2009). Molecular determinants of dysregulated GABAergic gene expression in the prefrontal cortex of subjects with schizophrenia. Biol. Psychiatry 65, 1006 1014. doi: 10.1016/j.biopsych.2008. 11.019

Meng, H., Liang, H. L., and WongRiley, M. (2007). Quantitative immuno-electron microscopic analysis of depolarization-induced expression of PGC-1alpha in cultured rat visual cortical neurons. Brain Res. 1175, 10-16. doi: 10. 1016/j.brainres.2007.07.063

Meyer, U., and Feldon, J. (2010). Epidemiology-driven neurodevelopmental animal models of schizophrenia. Prog. Neurobiol. 90, 285-326. doi: 10.1016/j.pneurobio. 2009.10.018

Meyer, U., Nyffeler, M., Yee, B. K., Knuesel, I., and Feldon, J. (2008). Adult brain and behavioral pathological markers of prenatal immune challenge during early/middle and late fetal development in mice. Brain Behav. Immun. 22, 469-486. doi: 10.1016/j.bbi.2007. 09.012

Meyer, U. (2013). Developmental neuroinflammation and schizophrenia. Prog. Neuropsychopharmacol. Biol. Psychiatry 42, 20-34. doi: 10.1016/j. pnpbp.2011.11.003

Mill, J., Tang, T., Kaminsky, Z., Khare, T., Yazdanpanah, S., Bouchard, L., et al. (2008). Epigenomic profiling reveals DNA-methylation change associated with major psychosis. Am. J. Hum. Genet. 82, 696-711. doi: 10.1016/j.ajhg.2008.01.008

Möller, M., Du Preez, J. L., Emsley, R., and Harvey, B. H. (2011). Isolation rearing-induced deficits in sensorimotor gating and social interaction in rats are related to cortico-striatal oxidative stress, and reversed by sub-chronic clozapine administration. Eur. Neuropsychopharmacol. 21, 471-483. doi: 10. 1016/j.euroneuro.2010.09.006

Mukerjee, S., Mahadik, S. P., Scheffer, R., Correnti, E. E., and Kelkar, H. (1996). Impaired antioxidant defense at the onset of psychosis. Schizophr. Res. 19, 19-26. doi: 10. 1016/0920-9964(95)00048-8

Murgatroyd, C., Patchev, A. V., Wu, Y., Micale, V., Bockmühl, Y., Fischer, D., et al. (2009). Dynamic DNA methylation programs persistent adverse effects of early-life stress. Nat. Neurosci. 12, 1559-1566. doi: 10.1038/nn.2436

Nafissi, S., Saadat, I., Farrashbandi, H., and Saadat, M. (2011). Association between three genetic polymorphisms of glutathione S-transferase Z1(GSTZ1) and susceptibility to schizophrenia. Psychiatry Res. 187, 314-315. doi: 10.1016/j.psychres. 2010.11.024

Nanduri, J., Makarenko, V., Reddy, V. D., Yuan, G., Pawar, A., Wang, N., et al. (2012). Epigenetic regulation of hypoxic sensing disrupts cardiorespiratory homeostasis. Proc. Natl. Acad. Sci. U S A 109, 25152520. doi: 10.1073/pnas.1120600109 Nakatani-Pawlak, A., Yamaguchi, K., Tatsumi, Y., Mizoguchi, H., and Yoneda, Y. (2009). Neonatal phencyclidine treatment in mice induces behavioral, histological and neurochemical abnormalities in adulthood. Biol. Pharm. Bull. 32, $1576-$ 1583. doi: 10.1248/bpb.32.1576

Nakazawa, K., Zsiros, V., Jiang, Z., Nakao, K., Kolata, S., Zhang, S., et al. (2012). GABAergic interneuron origin of schizophrenia pathophysiology. Neuropharmacology 62, 1574-1583. doi: 10.1016/j. neuropharm.2011.01.022 
Neddens, J., and Buonanno, A. (2010). Selective populations of hippocampal interneurons express ErbB4 and their number and distribution is altered in ErbB4 knockout mice. Hippocampus 20, 724-744. doi: 10. 1002/hipo.20675

Niatsetskaya, Z. V., Sosunov, S. A., Matsiukevich, D., Utkina-Sosunova, I. V., Ratner, V. I., Starkov, A. A., et al. (2012). The oxygen free radicals originating from mitochondrial complex I contribute to oxidative brain injury following hypoxia-ischemia in neonatal mice. J. Neurosci. 32, 3235-3244. doi: $\quad 10.1523 /$ jneurosci.6303-11. 2012

Niwa, M., Jaaro-Peled, H., Tankou, S., Seshadri, S., Hikida, T., Matsumoto, Y., et al. (2013). Adolescent stress-induced epigenetic control of dopaminergic neurons via glucocorticoids. Science 339, 335-339. doi: 10.1126/science.1226931

Oberlander, T. F., Weinberg, J., Papsdorf, M., Grunau, R., Misri, S., Devlin, A. M., et al. (2008). Prenatal exposure to maternal depression, neonatal methylation of human glucocorticoid receptor gene (NR3C1) and infant cortisol stress responses. Epigenetics 3, 97-106. doi: 10. 4161/epi.3.2.6034

O'Donnell, P. (2010). Adolescent maturation of cortical dopamine. Neurotox. Res. 18, 306-312. doi: 10. 1007/s12640-010-9157-3

O'Donnell, P. (2012). Cortical interneurons, immune factors and oxidative stress as early targets for schizophrenia. Eur. J. Neurosci. 35, 1866-1870. doi: 10.1111/j. 1460-9568.2012.08130.x

Oitzl, M. S., Champagne, D. L., van der Veen, R., and de Kloet, E. R. (2010). Brain development under stress: hypotheses of glucocorticoid actions revisited. Neurosci. Biobehav. Rev. 34, 853-866. doi: 10.1016/j. neubiorev.2009.07.006

Okaty, B. W., Miller, M. N., Sugino, K., Hempel, C. M., and Nelson, S. B. (2009). Transcriptional and electrophysiological maturation of neocortical fast-spiking GABAergic interneurons. J. Neurosci. 29, 7040-7052. doi: 10.1523/jneurosci. 0105-09.2009

Oskvig, D. B., Elkahloun, A. G., Johnson, K. R., Phillips, T. M., and Herkenham, M. (2012). Maternal immune activation by LPS selectively alters specific gene expression profiles of interneuron migration and oxidative stress in the fetus without triggering a fetal immune response. Brain Behav. Immun. 26,
623-634. doi: 10.1016/j.bbi.2012.01. 015

Owen, M. J., Craddock, N., and O'Donovan, M. C. (2005). Schizophrenia: genes at last? Trends Genet. 21, 518-525. doi: 10. 1016/j.tig.2005.06.011

Padurariu, M., Ciobica, A., Dobrin, I., and Stefanescu, C. (2010). Evaluation of antioxidant enzymes activities and lipid peroxidation in schizophrenic patients treated with typical and atypical antipsychotics. Neurosci. Lett. 479, 317-320. doi: 10. 1016/j.neulet.2010.05.088

Paintlia, M. K., Paintlia, A. S., Barbosa, E., Singh, I., and Singh, A. K. (2004). N-acetylcysteine prevents endotoxin-induced degeneration of oligodendrocyte progenitors and hypomyelination in developing rat brain. J. Neurosci. Res. 78, 347-361. doi: 10.1002/jnr.20261

Pangratz-Fuehrer, S., and Hestrin, S. (2011). Synaptogenesis of electrical and GABAergic synapses of fastspiking inhibitory neurons in the neocortex. J. Neurosci. 31, 1076710775. doi: 10.1523/JNEUROSCI. 6655-10.2011

Park, Y. U., Jeong, J., Lee, H., Mun, J. Y., Kim, J. H., Lee, J. S., et al. (2010). Disrupted-in-schizophrenia 1 (DISC1) plays essential roles in mitochondria in collaboration with mitofilin. Proc. Natl. Acad. Sci. U S A 107, 17785-17790. doi: 10. 1073/pnas. 1004361107

Pawelzik, H., Hughes, D. I., and Thomson, A. M. (2002). Physiological and morphological diversity of immunocytochemically defined parvalbumin- and cholecystokininpositive interneurones in CAl of the adult rat hippocampus. J. Comp. Neurol. 443, 346-367. doi: 10. 1002/cne. 10118

Perelló, M., Chacon, F., Cardinali, D. P., Esquifino, A. I., and Spinedi, E. (2006). Effect of social isolation on 24-h pattern of stress hormones and leptin in rats. Life Sci. 78, 18571862. doi: 10.1016/j.lfs.2005.08.029

Pierri, J. N., Chaudry, A. S., Woo, T. U., and Lewis, D. A. (1999). Alterations in chandelier neuron axon terminals in the prefrontal cortex of schizophrenic subjects. Am. J. Psychiatry 156, 1709-1719.

Pietersen, A. N., Lancaster, D. M., Patel, N., Hamilton, J. B., and Vreugdenhil, M. (2009). Modulation of gamma oscillations by endogenous adenosine through Al and $\mathrm{A} 2 \mathrm{~A}$ receptors in the mouse hippocampus. Neuropharmacology 56, 481-492. doi: 10.1016/j. neuropharm.2008.10.001
Pino, E., Wang, H., McDonald, M. E., Qiang, L., and Farmer, S. R. (2012). Roles for peroxisome proliferatoractivated receptor $\gamma(\operatorname{PPAR} \gamma)$ and $\operatorname{PPAR} \gamma$ coactivators $1 \alpha$ and $1 \beta$ in regulating response of white and brown adipocytes to hypoxia. J. Biol. Chem. 287, 18351-18358. doi: 10. 1074/jbc.M112.350918

Piontkewitz, Y., Bernstein, H. G., Dobrowolny, H., Bogerts, B., Weiner, I., Keilhoff, G., et al. (2012). Effects of risperidone treatment in adolescence on hippocampal neurogenesis, parvalbumin expression, and vascularization following prenatal immune activation in rats. Brain Behav. Immun. 26, 353-363. doi: 10.1016/j.bbi.2011.11.004

Powell, S. B., Sejnowski, T. J., and Behrens, M. M. (2012). Behavioral and neurochemical consequences of cortical oxidative stress on parvalbumin-interneuron maturation in rodent models of schizophrenia. Neuropharmacology 62, 1322-1331. doi: 10.1016/j. neuropharm.2011.01.049

Prabakaran, S., Swatton, J. E., Ryan, M. M., Huffaker, S. J., Huang, J. T., Griffin, J. L., et al. (2004). Mitochondrial dysfunction in schizophrenia: evidence for compromised brain metabolism and oxidative stress. Mol. Psychiatry 9, 684-697, 643. doi: 10.1038/sj.mp.4001532

Provençal, N., Suderman, M. J., Guillemin, C., Massart, R., Ruggiero, A., Wang, D., et al. (2012). The signature of maternal rearing in the methylome in rhesus macaque prefrontal cortex and $\mathrm{T}$ cells. J. Neurosci. 32, 15626-15642. doi: 10. 1523/jneurosci.1470-12.2012

Puddifoot, C., Martel, M. A., Soriano, F. X., Camacho, A., Vidal-Puig, A. Wyllie, D. J., et al. (2012). PGC-1 $\alpha$ negatively regulates extrasynaptic NMDAR activity and excitotoxicity. J. Neurosci. 32, 6995-7000. doi: 10. 1523/JNEUROSCI.6407-11.2012

Puigserver, P., Wu, Z., Park, C. W., Graves, R., Wright, M., and Spiegelman, B. M. (1998). A cold-inducible coactivator of nuclear receptors linked to adaptive thermogenesis. Cell 92, 829-839. doi: 10. 1016/s0092-8674(00)81410-5

Purcell, S. M., Wray, N. R., Stone, J. L., Visscher, P. M., O’Donovan, M. C., Sullivan, P. F., et al. (2009). Common polygenic variation contributes to risk of schizophrenia and bipolar disorder. Nature 460, 748-752. doi: 10.1038/nature08185

Qin, W., Haroutunian, V., Katsel, P., Cardozo, C. P., Ho, L., Buxbaum, J. D., et al. (2009). PGC- 1alpha expression decreases in the Alzheimer disease brain as a function of dementia. Arch. Neurol. 66, 352-361. doi: 10.1001/archneurol. 2008.588

Radonjic, N. V., Knezevic, I. D., Vilimanovich, U., Kravic-Stevovic, T., Marina, L. V., Nikolic, T., et al. (2010). Decreased glutathione levels and altered antioxidant defense in an animal model of schizophrenia: long-term effects of perinatal phencyclidine administration. Neuropharmacology 58, 739-745. doi: 10.1016/j.neuropharm.2009.12. 009

Raffa, M., Mechri, A., Othman, L. B., Fendri, C., Gaha, L., Kerkeni, A., et al. (2009). Decreased glutathione levels and antioxidant enzyme activities in untreated and treated schizophrenic patients. Prog. Neuropsychopharmacol. Biol. Psychiatry 33, 1178-1183. doi: 10.1016/j. pnpbp.2009.06.018

Ranjekar, P. K., Hinge, A., Hegde, M. V., Ghate, M., Kale, A., Sitasawad, S., et al. (2003). Decreased antioxidant enzymes and membrane essential polyunsaturated fatty acids in schizophrenic and bipolar mood disorder patients. Psychiatry Res. 121, 109-122. doi: 10. 1016/s0165-1781(03)00220-8

Reddy, R., Keshavan, M., and Yao, J. K. (2003). Reduced plasma antioxidants in first-episode patients with schizophrenia. Schizophr. Res. 62, 205-212. doi: 10.1016/s09209964(02)00407-3

Reddy, R., Sahebarao, M. P., Mukherjee, S., and Murthy, J. N. (1991). Enzymes of the antioxidant defense system in chronic schizophrenic patients. Biol. Psychiatry 30, 409-412. doi: 10.1016/00063223(91)90298-z

Rhee, J., Ge, H., Yang, W., Fan, M., Handschin, C., Cooper, M., et al. (2006). Partnership of PGC-1alpha and HNF4alpha in the regulation of lipoprotein metabolism. J. Biol. Chem. 281, 14683-14690. doi: 10. 1074/jbc.M512636200

Rodriguez, E., George, N., Lachaux, J. P., Martinerie, J., Renault, B., Varela, F. J., et al. (1999). Perception's shadow: long-distance synchronization of human brain activity. Nature 397, 430-433. doi: 10.1038/17120

Ross, C. A., Margolis, R. L., Reading, S. A., Pletnikov, M., and Coyle, J. T. (2006). Neurobiology of schizophrenia. Neuron 52, 139 153. doi: 10.1016/j.neuron.2006. 09.015

Rudy, B., Fishell, G., Lee, S., and Hjerling-Leffler, J. (2011). Three 
groups of interneurons account for nearly $100 \%$ of neocortical GABAergic neurons. Dev. Neurobiol. 71, 45-61. doi: 10.1002/dneu.20853

Rudy, B., and McBain, C. J. (2001). Kv3 channels: voltage-gated $\mathrm{K}+$ channels designed for high-frequency repetitive firing. Trends Neurosci. 24, 517-526. doi: 10.1016/s01662236(00)01892-0

Ruscio, M. G., Sweeny, T., Hazelton, J., Suppatkul, P., and Sue Carter, C. (2007). Social environment regulates corticotropin releasing factor, corticosterone and vasopressin in juvenile prairie voles. Horm. Behav. 51, 54-61. doi: 10.1016/j.yhbeh. 2006.08.004

Ruzicka, W. B., Zhubi, A., Veldic, M., Grayson, D. R., Costa, E., Guidotti, A., et al. (2007). Selective epigenetic alteration of layer I GABAergic neurons isolated from prefrontal cortex of schizophrenia patients using laser-assisted microdissection. Mol. Psychiatry 12, 385-397. doi: 10. 1038/sj.mp.4001954

Saadat, M., Mobayen, F., and Farrashbandi, H. (2007). Genetic polymorphism of glutathione Stransferase T1: a candidate genetic modifier of individual susceptibility to schizophrenia. Psychiatry Res. 153, 87-91. doi: 10.1016/j.psychres. 2006.03.024

Sahin, E., and Gumuslu, S. (2007). Immobilization stress in rat tissues: alterations in protein oxidation, lipid peroxidation and antioxidant defense system. Comp. Biochem. Physiol. C Toxicol. Pharmacol. 144, 342-347. doi: 10.1016/j.cbpc.2006. 10.009

Sakata, K., Woo, N. H., Martinowich, K., Greene, J. S., Schloesser, R. J., Shen, L., et al. (2009). Critical role of promoter IV-driven BDNF transcription in GABAergic transmission and synaptic plasticity in the prefrontal cortex. Proc. Natl. Acad. Sci. U S A 106, 5942-5947. doi: 10.1073/pnas.0811431106

Salin, P., López, I. P., Kachidian, P., Barroso-Chinea, P., Rico, A. J., Gómez-Bautista, V., et al. (2009). Changes to interneuron-driven striatal microcircuits in a rat model of Parkinson's disease. Neurobiol. Dis. 34, 545-552. doi: 10.1016/j. nbd.2009.03.006

Scarpulla, R. C. (2011). Metabolic control of mitochondrial biogenesis through the PGC-1 family regulatory network. Biochim. Biophys. Acta 1813, 1269-1278. doi: 10. 1016/j.bbamcr.2010.09.019

Scarpulla, R. C., Vega, R. B., and Kelly, D. P. (2012). Transcriptional inte- gration of mitochondrial biogenesis. Trends Endocrinol. Metab. 23, 459466. doi: 10.1016/j.tem.2012. 06.006

Schiavone, S., Jaquet, V., Sorce, S., Dubois-Dauphin, M., Hultqvist, M., Bäckdahl, L., et al. (2012). NADPH oxidase elevations in pyramidal neurons drive psychosocial stress-induced neuropathology. Transl. Psychiatry 2:e111. doi: 10. 1038/tp.2012.36

Schiavone, S., Sorce, S., DuboisDauphin, M., Jaquet, V., Colaianna, M., Zotti, M., et al. (2009). Involvement of NOX2 in the development of behavioral and pathologic alterations in isolated rats. Biol. Psychiatry 66, 384-392. doi: 10. 1016/j.biopsych.2009.04.033

Schreiber, S. N., Emter, R., Hock, M. B., Knutti, D., Cardenas, J., Podvinec, M., et al. (2004). The estrogenrelated receptor alpha (ERRalpha) functions in PPARgamma coactivator 1alpha (PGC-lalpha)-induced mitochondrial biogenesis. Proc. Natl. Acad. Sci. U S A 101, 64726477. doi: 10.1073/pnas.0308686101

Seelan, R. S., and Grossman, L. I. (1997). Structural organization and promoter analysis of the bovine cytochrome c oxidase subunit VIIc gene. A functional role for YY1. J. Biol. Chem. 272, 10175-10181. doi: 10.1074/jbc.272.15.10175

Sheldon, R. A., Christen, S., and Ferriero, D. M. (2008). Genetic and pharmacologic manipulation of oxidative stress after neonatal hypoxia-ischemia. Int. J. Dev. Neurosci. 26, 87-92. doi: 10.1016/j. ijdevneu.2007.08.010

Shen, S., Lang, B., Nakamoto, C., Zhang, F., Pu, J., Kuan, S. L., et al. (2008). Schizophrenia-related neural and behavioral phenotypes in transgenic mice expressing truncated disc1. J. Neurosci. 28, $10893-$ 10904. doi: 10.1523/jneurosci. 3299-08.2008

Shin, J. H., Ko, H. S., Kang, H., Lee, Y., Lee, Y. I., Pletinkova, O., et al. (2011). PARIS (ZNF746) repression of PGC- $1 \alpha$ contributes to neurodegeneration in Parkinson's disease. Cell 144, 689-702. doi: 10.1016/j. cell.2011.02.010

Siegel, M., Donner, T. H., Oostenveld, R., Fries, P., and Engel, A. K. (2008). Neuronal synchronization along the dorsal visual pathway reflects the focus of spatial attention. Neuron 60, 709-719. doi: 10.1016/j.neuron. 2008.09.010

Smoller, J. W., Craddock, N., Kendler, K., Lee, P. H., Neale, B. M., Nurnberger, J. I., et al. (2013). Iden- tification of risk loci with shared effects on five major psychiatric disorders: a genome-wide analysis. Lancet 381, 1371-1379. doi: 10. 1016/s0140-6736(12)62129-1

Sohal, V. S., Zhang, F., Yizhar, O., and Deisseroth, K. (2009). Parvalbumin neurons and gamma rhythms enhance cortical circuit performance. Nature 459, 698-702. doi: 10.1038/nature07991

Spencer, K. M., Nestor, P. G., Perlmutter, R., Niznikiewicz, M. A., Klump, M. C., Frumin, M., et al. (2004). Neural synchrony indexes disordered perception and cognition in schizophrenia. Proc. Natl. Acad. Sci. U S A 101, 17288-17293. doi: 10. 1073/pnas.0406074101

Stefansson, H., Rujescu, D., Cichon, S., Pietiläinen, O. P., Ingason, A., Steinberg, S., et al. (2008). Large recurrent microdeletions associated with schizophrenia. Nature 455, 232-236. doi: 10.1038/nature07229

Steullet, P., Cabungcal, J. H., Kulak, A., Kraftsik, R., Chen, Y., Dalton, T. P., et al. (2010). Redox dysregulation affects the ventral but not dorsal hippocampus: impairment of parvalbumin neurons, gamma oscillations, and related behaviors. J. Neurosci. 30, 2547-2558. doi: 10.1523/jneurosci.3857-09. 2010

St-Pierre, J., Drori, S., Uldry, M., Silvaggi, J. M., Rhee, J., Jäger, S., et al. (2006). Suppression of reactive oxygen species and neurodegeneration by the PGC-1 transcriptional coactivators. Cell 127, 397-408. doi: 10.1016/j.cell.2006.09.024

Stone, J. L., O’Donovan, M. C., Gurling, H., Kirov, G. K., Blackwood, D. H., Corvin, A., et al. (2008). Rare chromosomal deletions and duplications increase risk of schizophrenia. Nature 455, 237-241. doi: $10.1038 /$ nature07239

Straub, R. E., and Weinberger, D. R. (2006). Schizophrenia genes famine to feast. Biol. Psychiatry 60, 81-83. doi: 10.1016/j.biopsych. 2006.06.002

Suboticanec, K., Folnegovic-Smalc, V., Korbar, M., Mestrovic, B., and Buzina, R. (1990). Vitamin C status in chronic schizophrenia. Biol. Psychiatry 28, 959-966. doi: 10. 1016/0006-3223(90)90061-6

Sullivan, P. F., Kendler, K. S., and Neale, M. C. (2003). Schizophrenia as a complex trait: evidence from a meta-analysis of twin studies. Arch. Gen. Psychiatry 60, 1187-1192. doi: 10.1001/archpsyc.60.12.1187

Sunahori, K., Juang, Y. T., and Tsokos, G. C. (2009). Methylation status of $\mathrm{CpG}$ islands flanking a cAMP response element motif on the protein phosphatase $2 \mathrm{Ac}$ alpha promoter determines CREB binding and activity. J. Immunol. 182, 1500-1508.

Symond, M. P., Harris, A. W., Gordon, E., and Williams, L. M. (2005). "Gamma synchrony" in firstepisode schizophrenia: a disorder of temporal connectivity?. Am. J. Psychiatry 162, 459-465. doi: 10. 1176/appi.ajp.162.3.459

Tansey, E. P., Chow, A., Rudy, B., and McBain, C. J. (2002). Developmental expression of potassium-channel subunit Kv3.2 within subpopulations of mouse hippocampal inhibitory interneurons. Hippocampus 12, 137-148. doi: 10.1002/hipo. 1104

Tienari, P., Wynne, L. C., Sorri, A., Lahti, I., Läksy, K., Moring, J., et al. (2004). Genotype-environment interaction in schizophreniaspectrum disorder. Long-term follow-up study of finnish adoptees. Br. J. Psychiatry 184, 216-222. doi: 10.1192/bjp.184.3.216

Tosic, M., Ott, J., Barral, S., Bovet, P., Deppen, P., Gheorghita, F., et al. (2006). Schizophrenia and oxidative stress: glutamate cysteine ligase modifier as a susceptibility gene. Am. J. Hum. Genet. 79, 586-592. doi: 10.1086/507566

Toth, M., Mikics, E., Tulogdi, A., Aliczki, M., and Haller, J. (2011). Post-weaning social isolation induces abnormal forms of aggression in conjunction with increased glucocorticoid and autonomic stress responses. Horm. Behav. 60, 28-36. doi: 10.1016/j.yhbeh.2011.02.003

Tsankova, N. M., Berton, O., Renthal, W., Kumar, A., Neve, R. L., Nestler, E. J., et al. (2006). Sustained hippocampal chromatin regulation in a mouse model of depression and antidepressant action. Nat. Neurosci. 9, 519-525. doi: 10.1038/nn1659

Tseng, K. Y., Lewis, B. L., Hashimoto, T., Sesack, S. R., Kloc, M., Lewis, D. A., et al. (2008). A neonatal ventral hippocampal lesion causes functional deficits in adult prefrontal cortical interneurons. J. Neurosci. 28, 12691-12699. doi: 10. 1523/jneurosci.4166-08.2008

Tseng, K. Y., and O'Donnell, P. (2007). Dopamine modulation of prefrontal cortical interneurons changes during adolescence. Cereb. Cortex 17, 1235-1240. doi: 10. 1093/cercor/bhl034

Uhlhaas, P. J., Roux, F., Singer, W., Haenschel, C., Sireteanu, R., and Rodriguez, E. (2009). The develop- 
ment of neural synchrony reflects late maturation and restructuring of functional networks in humans. Proc. Natl. Acad. Sci. U S A 106, 9866-9871. doi: 10.1073/pnas. 0900390106

Uhlhaas, P. J., and Singer, W. (2010). Abnormal neural oscillations and synchrony in schizophrenia. Nat. Rev. Neurosci. 11, 100-113. doi: 10. 1038/nrn2774

Uldry, M., Yang, W., St-Pierre, J., Lin, J., Seale, P., Spiegelman, B. M., et al. (2006). Complementary action of the PGC- 1 coactivators in mitochondrial biogenesis and brown fat differentiation. Cell Metab. 3, 333-341. doi: 10.1016/j.cmet.2006. 04.002

Uranova, N., Orlovskaya, D., Vikhreva, O., Zimina, I., Kolomeets, N., Vostrikov, V., et al. (2001). Electron microscopy of oligodendroglia in severe mental illness. Brain Res. Bull. 55, 597-610. doi: 10. 1016/s0361-9230(01)00528-7

Van de Berg, W. D., Kwaijtaal, M., de Louw, A. J., Lissone, N. P., Schmitz, C., Faull, R. L., et al. (2003). Impact of perinatal asphyxia on the GABAergic and locomotor system. Neuroscience 117, 83-96. doi: 10. 1016/s0306-4522(02)00787-x

van Os, J., Kenis, G., and Rutten, B. P. (2010). The environment and schizophrenia. Nature 468, 203-212. doi: 10.1038/nature09563

Veldic, M., Guidotti, A., Maloku, E., Davis, J. M., and Costa, E. (2005). In psychosis, cortical interneurons overexpress DNA-methyltransferase 1. Proc. Natl. Acad. Sci. U S A 102, 2152-2157. doi: 10.1073/pnas. 0409665102

Volk, D. W., Matsubara, T., Li, S., Sengupta, E. J., Georgiev, D., Minabe, Y., et al. (2012). Deficits in transcriptional regulators of cortical parvalbumin neurons in schizophrenia. Am. J. Psychiatry 169, 1082-1091. doi: 10.1176/appi. ajp.2012.12030305

Volk, D. W., Pierri, J. N., Fritschy, J. M., Auh, S., Sampson, A. R., Lewis, D. A., et al. (2002). Reciprocal alterations in pre- and postsynaptic inhibitory markers at chandelier cell inputs to pyramidal neurons in schizophrenia. Cereb. Cortex 12, 1063-1070. doi: 10.1093/cercor/12. 10.1063

Volz, H. P., Rzanny, R., May, S., Hegewald, H., Preussler, B., Hajek, M., et al. (1997). 31P magnetic resonance spectroscopy in the dorsolateral prefrontal cortex of schizophrenics with a volume selective techniquepreliminary findings. Biol. Psy- chiatry 41, 644-648. doi: 10. 1016/s0006-3223(96)00062-5

Walsh, T., McClellan, J. M., McCarthy, S. E., Addington, A. M., Pierce, S. B., Cooper, G. M., et al. (2008). Rare structural variants disrupt multiple genes in neurodevelopmental pathways in schizophrenia. Science 320, 539-543. doi: 10.1126/science. 1155174

Wang, C. Z., Yang, S. F., Xia, Y., and Johnson, K. M. (2008). Postnatal phencyclidine administration selectively reduces adult cortical parvalbumin-containing interneurons. Neuropsychopharmacology 33, 2442-2455. doi: 10.1038/sj.npp. 1301647

Wang, H. X., and Gao, W. J. (2009). Cell type-specific development of NMDA receptors in the interneurons of rat prefrontal cortex. $\mathrm{Neu}$ ropsychopharmacology 34, 20282040. doi: $10.1038 / \mathrm{npp} .2009 .20$

Wang, H. X., and Gao, W. J. (2010). Development of calcium-permeable AMPA receptors and their correlation with NMDA receptors in fast-spiking interneurons of rat prefrontal cortex. J. Physiol. 588(Pt 15), 2823-2838. doi: 10.1113/jphysiol. 2010.187591

Wang, J. F., Shao, L., Sun, X., and Young, L. T. (2009). Increased oxidative stress in the anterior cingulate cortex of subjects with bipolar disorder and schizophrenia. Bipolar Disord. 11, 523-529. doi: 10. 1111/j.1399-5618.2009.00717.x

Wang, Y., Zhan, L., Zeng, W., Li, K., Sun, W., Xu, Z. C., et al. (2011). Downregulation of hippocampal GABA after hypoxia-induced seizures in neonatal rats. $\mathrm{Neu}$ rochem. Res. 36, 2409-2416. doi: 10. 1007/s11064-011-0565-4

Wareski, P., Vaarmann, A., Choubey, V., Safiulina, D., Liiv, J., Kuum, M., et al. (2009). PGC-1\{alpha\} and PGC-1\{beta\} regulate mitochondrial density in neurons. J. Biol. Chem. 284, 21379-21385. doi: 10. 1074/jbc.m109.018911

Weaver, I. C., Cervoni, N., Champagne, F. A., D'Alessio, A. C., Sharma, S., Seckl, J. R., et al. (2004). Epigenetic programming by maternal behavior. Nat. Neurosci. 7, 847-854. doi: 10. 1038/nn1276

Weaver, I. C. (2009). Epigenetic effects of glucocorticoids. Semin. Fetal Neonatal Med. 14, 143-150. doi: 10. 1016/j.siny.2008.12.002

Weickert, C. S., Hyde, T. M., Lipska, B. K., Herman, M. M., Weinberger, D. R., and Kleinman, J. E. (2003). Reduced brain-derived neurotrophic factor in prefrontal cortex of patients with schizophrenia. Mol. Psychiatry 8, 592-610. doi: 10. 1038/sj.mp.4001308

Weickert, C. S., Ligons, D. L., Romanczyk, T., Ungaro, G., Hyde, T. M., Herman, M. M., et al. (2005). Reductions in neurotrophin receptor mRNAs in the prefrontal cortex of patients with schizophrenia. Mol. Psychiatry 10, 637-650. doi: 10. 1038/sj.mp.4001678

Weinberger, D. R. (1987). Implications of normal brain development for the pathogenesis of schizophrenia. Arch. Gen. Psychiatry 44, 660669. doi: 10.1001/archpsyc.1987. 01800190080012

Weintraub, A., Singaravelu, J., and Bhatnagar, S. (2010). Enduring and sex-specific effects of adolescent social isolation in rats on adult stress reactivity. Brain Res. 1343, 83-92. doi: 10.1016/j.brainres.2010.04.068

Weiss, I. C., Pryce, C. R., Jongen-Rêlo, A. L., Nanz-Bahr, N. I., and Feldon, J. (2004). Effect of social isolation on stress-related behavioural and neuroendocrine state in the rat. Behav. Brain Res. 152, 279-295. doi: 10.1016/j.bbr.2003.10.015

Weydt, P., Pineda, V. V., Torrence, A. E., Libby, R. T., Satterfield, T. F., Lazarowski, E. R., et al. (2006). Thermoregulatory and metabolic defects in Huntington's disease transgenic mice implicate PGClalpha in Huntington's disease neurodegeneration. Cell Metab. 4, 349-362. doi: 10.1016/j.cmet.2006. 10.004

Whittaker, R. G., Turnbull, D. M., Whittington, M. A., and Cunningham, M. O. (2011). Impaired mitochondrial function abolishes gamma oscillations in the hippocampus through an effect on fast-spiking interneurons. Brain 134(Pt 7), e180; author reply e181. doi: 10.1093/brain/awr018

Williams, J. B., Pang, D., Delgado, B., Kocherginsky, M., Tretiakova, M., Krausz, T., et al. (2009). A model of gene-environment interaction reveals altered mammary gland gene expression and increased tumor growth following social isolation. Cancer Prev. Res. (Phila.) 2, 850-861. doi: 10.1158/1940-6207. capr-08-0238

Woo, N. H., and Lu, B. (2006). Regulation of cortical interneurons by neurotrophins: from development to cognitive disorders. Neuroscientist 12, 43-56. doi: 10. $1177 / 1073858405284360$

Woo, T. U., Whitehead, R. E., Melchitzky, D. S., and Lewis, D. A. (1998). A subclass of prefrontal gamma-aminobutyric acid axon terminals are selectively altered in schizophrenia. Proc. Natl. Acad. Sci. U S A 95, 5341-5346. doi: 10. 1073/pnas.95.9.5341

Wu, X., Fu, Y., Knott, G., Lu, J., Di Cristo, G., and Huang, Z. J. (2012). GABA signaling promotes synapse elimination and axon pruning in developing cortical inhibitory interneurons. J. Neurosci. 32, 331-343. doi: 10.1523/jneurosci. 3189-11.2012

Wu, Z., Puigserver, P., Andersson, U., Zhang, C., Adelmant, G., Mootha, V., et al. (1999). Mechanisms controlling mitochondrial biogenesis and respiration through the thermogenic coactivator PGC-1. Cell 98, 115-124. doi: 10.1016/s00928674(00)80611-x

Wynn, J. K., Light, G. A., Breitmeyer, B., Nuechterlein, K. H., and Green, M. F. (2005). Event-related gamma activity in schizophrenia patients during a visual backward-masking task. Am. J. Psychiatry 162, 23302336. doi: 10.1176/appi.ajp.162.12. 2330

Xi, H., Yu, Y., Fu, Y., Foley, J., Halees, A., Weng, Z., et al. (2007). Analysis of overrepresented motifs in human core promoters reveals dual regulatory roles of YY1. Genome Res. 17, 798-806. doi: 10.1101/gr.5754707

Xu, B., Roos, J. L., Levy, S., van Rensburg, E. J., Gogos, J. A., Karayiorgou, M., et al. (2008). Strong association of de novo copy number mutations with sporadic schizophrenia. Nat. Genet. 40, 880-885. doi: 10.1038/ng.162

Xu, D. X., Chen, Y. H., Wang, H., Zhao, L., Wang, J. P., Wei, W., et al. (2005). Effect of N-acetylcysteine on lipopolysaccharide-induced intra-uterine fetal death and intrauterine growth retardation in mice. Toxicol. Sci. 88, 525-533. doi: 10. 1093/toxsci/kfi300

Yang, J. M., Zhang, J., Yu, Y. Q., Duan, S., and Li, X. M. (2012). Postnatal development of 2 microcircuits involving fast-spiking interneurons in the mouse prefrontal cortex. Cereb. Cortex doi: 10.1093/cercor/ bhs291. [Epub ahead of print].

Yao, J. K., and Keshavan, M. S. (2011). Antioxidants, redox signaling, and pathophysiology in schizophrenia: an integrative view. Antioxid. Redox Signal. 15, 2011-2035. doi: 10. 1089/ars.2010.3603

Yao, J. K., Leonard, S., and Reddy, R. (2006). Altered glutathione redox state in schizophrenia. Dis. Markers 22, 83-93. doi: 10. $1155 / 2006 / 248387$ 
Yao, J. K., Reddy, R., and van Kammen, D. P. (1998). Reduced level of plasma antioxidant uric acid in schizophrenia. Psychiatry Res. 80, 29-39. doi: 10.1016/s01651781(98)00051-1

Yao, J. K., Reddy, R., and van Kammen, D. P. (2000). Abnormal age-related changes of plasma antioxidant proteins in schizophrenia. Psychiatry Res. 97, 137-151. doi: 10. 1016/s0165-1781(00)00230-4

Yoon, J. C., Puigserver, P., Chen, G., Donovan, J., Wu, Z., Rhee, J., et al. (2001). Control of hepatic gluconeogenesis through the transcriptional coactivator PGC-1. Nature 413, 131-138. doi: 10. 1038/35093050

Yu, L., and Yang, S. J. (2010). AMPactivated protein kinase mediates activity-dependent regulation of peroxisome proliferator-activated receptor gamma coactivator-1alpha and nuclear respiratory factor 1 expression in rat visual cortical neurons. Neuroscience 169, 23-38. doi: 10.1016/j.neuroscience.2010. 04.063
Zhang, X. Y., Tan, Y. L., Cao, L. Y., Wu, G. Y., Xu, Q., Shen, Y., et al. (2006). Antioxidant enzymes and lipid peroxidation in different forms of schizophrenia treated with typical and atypical antipsychotics. Schizophr. Res. 81, 291-300. doi: 10. 1016/j.schres.2005.10.011

Zhang, Y., Behrens, M. M., and Lisman, J. E. (2008). Prolonged exposure to NMDAR antagonist suppresses inhibitory synaptic transmission in prefrontal cortex. J. Neurophysiol. 100, 959-965. doi: 10.1152/jn. 00079.2008

Zhao, J., Li, L., Pei, Z., Li, C., Wei, H., Zhang, B., et al. (2012). Peroxisome proliferator activated receptor (PPAR) $-\gamma$ co-activator $1-\alpha$ and hypoxia induced factor- $1 \alpha$ mediate neuro- and vascular protection by hypoxic preconditioning in vitro. Brain Res. 1447, 1-8. doi: 10.1016/j. brainres.2012.01.059

Zhao, Y., Flandin, P., Long, J. E., Cuesta, M. D., Westphal, H., Rubenstein, J. L., et al. (2008). Distinct molecular pathways for development of telencephalic interneuron sub- types revealed through analysis of Lhx6 mutants. J. Comp. Neurol. 510, 79-99. doi: 10.1002/cne. 21772

Zheng, B., Liao, Z., Locascio, J. J., Lesniak, K. A., Roderick, S. S., Watt, M. L., et al. (2010). PGC- $1 \alpha$, a potential therapeutic target for early intervention in Parkinson's disease. Sci. Transl. Med. 2:52ra73. doi: 10. 1126/scitranslmed.3001059

Zhu, J. P., Xu, W., and Angulo, J. A. (2006). Methamphetamine-induced cell death: selective vulnerability in neuronal subpopulations of the striatum in mice. Neuroscience 140, 607-622. doi: 10.1016/j. neuroscience.2006.02.055

Zhu, L., Wang, Q., Zhang, L., Fang, Z., Zhao, F., Lv, Z., et al. (2010). Hypoxia induces PGC- $1 \alpha$ expression and mitochondrial biogenesis in the myocardium of TOF patients. Cell Res. 20, 676-687. doi: 10. 1038/cr.2010.46

Conflict of Interest Statement: The authors declare that the research was conducted in the absence of any commercial or financial relationships that could be construed as a potential conflict of interest.

Received: 12 July 2013; paper pending published: 30 July 2013; accepted: 13 August 2013; published online: 03 September 2013.

Citation: Jiang Z, Cowell RM and Nakazawa K (2013) Convergence of genetic and environmental factors on parvalbumin-positive interneurons in schizophrenia. Front. Behav. Neurosci. 7:116. doi:10.3389/fnbeh.2013. 00116

This article was submitted to the journal Frontiers in Behavioral Neuroscience. Copyright (C) 2013 Jiang, Cowell and Nakazawa. This is an open-access article distributed under the terms of the Creative Commons Attribution License (CC BY). The use, distribution or reproduction in other forums is permitted, provided the original author(s) or licensor are credited and that the original publication in this journal is cited, in accordance with accepted academic practice. No use, distribution or reproduction is permitted which does not comply with these terms. 